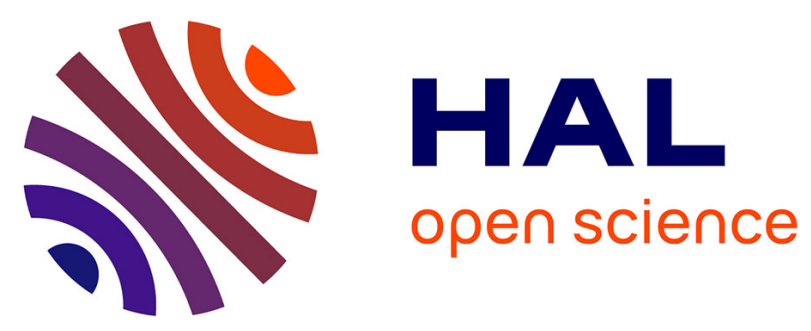

\title{
Serotonin 2B Receptor by Interacting with NMDA Receptor and CIPP Protein Complex May Control Structural Plasticity at Glutamatergic Synapses
}

Amina Benhadda, Emily Quentin, Imane Moutkine, Benjamin Chanrion, Marion Russeau, Philippe Marin, Sabine Lévi, Luc Maroteaux

\section{To cite this version:}

Amina Benhadda, Emily Quentin, Imane Moutkine, Benjamin Chanrion, Marion Russeau, et al.. Serotonin 2B Receptor by Interacting with NMDA Receptor and CIPP Protein Complex May Control Structural Plasticity at Glutamatergic Synapses. ACS Chemical Neuroscience, 2021, 10.1021/acschemneuro.0c00638 . hal-03176117

\section{HAL Id: hal-03176117 https://hal.science/hal-03176117}

Submitted on 22 Mar 2021

HAL is a multi-disciplinary open access archive for the deposit and dissemination of scientific research documents, whether they are published or not. The documents may come from teaching and research institutions in France or abroad, or from public or private research centers.
L'archive ouverte pluridisciplinaire HAL, est destinée au dépôt et à la diffusion de documents scientifiques de niveau recherche, publiés ou non, émanant des établissements d'enseignement et de recherche français ou étrangers, des laboratoires publics ou privés. 
Title: The serotonin $2 B$ receptor by interacting with NMDA receptor and CIPP protein complex may control structural plasticity at glutamatergic synapses

Authors list: Amina Benhadda ${ }^{1 *}$, Emily Quentin ${ }^{1 *}$, Imane Moutkine ${ }^{1}$, Benjamin Chanrion ${ }^{2}$, Marion Russeau ${ }^{1}$, Philippe Marin ${ }^{2}$, Sabine Levi $^{1} \#$, and Luc Maroteaux ${ }^{1} \#$

\begin{abstract}
The serotonin 2B (5- $\left.\mathrm{HT}_{2 \mathrm{~B}}\right)$ receptor coupled to Gq-protein contributes to the control of neuronal excitability and is implicated in various psychiatric disorders. The mechanisms underlying its brain function are not fully described. Using peptide affinity chromatography combined with mass spectrometry, we found that the PDZ binding motif of the 5- $\mathrm{HT}_{2 \mathrm{~B}}$ receptor located at its $\mathrm{C}$ terminal end interacts with the scaffolding protein Channel Interacting PDZ Protein (CIPP). We then showed in COS-7 cells that the association of the 5- $\mathrm{HT}_{2 \mathrm{~B}}$ receptor to CIPP enhanced receptoroperated inositol phosphate (IP) production without affecting its cell surface and intracellular levels. Co-immunoprecipitation experiments revealed that CIPP, the 5- $\mathrm{HT}_{2 \mathrm{~B}}$ receptor, and the NR1 subunit of the NMDA receptor form a macromolecular complex. CIPP increased 5- $\mathrm{HT}_{2 \mathrm{~B}}$ receptor clustering at the surface of primary cultured hippocampal neurons and prevented receptor dispersion following agonist stimulation, thus potentiating IP production and intracellular calcium mobilization in dendrites. CIPP or 5- $\mathrm{HT}_{2 \mathrm{~B}}$ receptor stimulation in turn dispersed NR1 clusters colocalized with 5$\mathrm{HT}_{2 \mathrm{~B}}$ receptors and increased the density and maturation of dendritic spines. Collectively, our results suggest that the $5-\mathrm{HT}_{2 \mathrm{~B}}$ receptor, the NMDA receptor and CIPP may form a signaling platform by which serotonin can influence structural plasticity of excitatory glutamatergic synapses.
\end{abstract}

\title{
Keywords:
}

Serotonin, scaffolding protein, synaptic plasticity, hippocampal neurons, NMDA receptor 


\section{TOC graphic}

5-HT2B

\section{5-HT2B+CIPP}

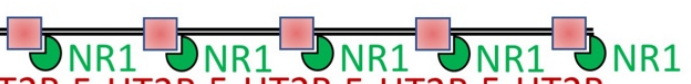

5-HT2B 5-HT2B 5-HT2B 5-HT2B 5-HT2B

5-HT2B C-ter

overexpression

$\uparrow$
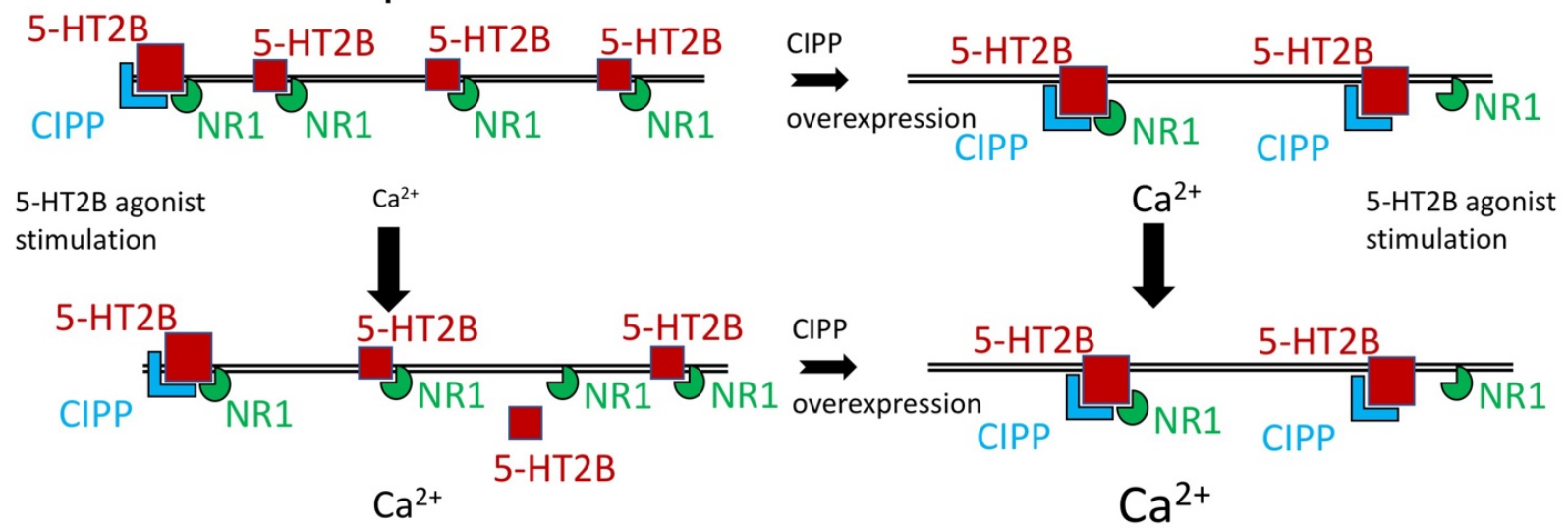


\section{Introduction}

Serotonin (5-HT) is a neurotransmitter involved in many physiological functions (sleep, mood, food intake...) and pathological conditions such as addiction, impulsivity, psychosis and depression. The variety of serotonin actions reflects the presence of numerous receptor subtypes. The serotonin receptor subtype 2 family comprises $5-\mathrm{HT}_{2 \mathrm{~A}}, 5-\mathrm{HT}_{2 \mathrm{~B}}$ and $5-\mathrm{HT}_{2 \mathrm{C}}$ receptors that are Gaq-coupled receptors. The 5- $\mathrm{HT}_{2 \mathrm{~B}}$ receptor is expressed in several areas of the brain, including cortex, hippocampus, raphe, habenula and cerebellum in the human ${ }^{1}$, in the rat ${ }^{2,3}$, and in the mouse ${ }^{4}$ brain. In addition, this receptor has been shown to be expressed in serotonin ${ }^{5,6}$ and dopamine ${ }^{7}$ neurons and in microglia ${ }^{8}$.

In humans, a loss-of-function polymorphism of 5- $\mathrm{HT}_{2 \mathrm{~B}}$ receptor gene $H T R 2 B$ is associated with impulsive and aggressive behaviors ${ }^{l}$. Other $H T R 2 B$ polymorphisms have been associated with cannabis-related aggression ${ }^{9}$ and cocaine-crack use ${ }^{10}$. Accordingly, $H t r 2 b^{-/-}$mice display impulsive behavior $^{1}$, a stronger response to cocaine ${ }^{7}$, and a global deficit in sensorimotor gating as well as novelty-induced hyperlocomotion, phenotypes related to positive symptoms of schizophrenia ${ }^{11}$. These disorders are commonly associated to the serotoninergic system. In hippocampal neurons, 5$\mathrm{HT}_{2 \mathrm{~B}}$ receptor activation prevents the stress-induced inhibition of long-term potentiation (LTP) ${ }^{12}$. In a neuropathic pain model, 5- $\mathrm{HT}_{2 \mathrm{~B}}$ receptor stimulation potentiates NMDA receptor activity in dorsal horn neurons ${ }^{13}$. Likewise, electrophysiological studies showed that $5-\mathrm{HT}_{2 \mathrm{~B}}$ receptor activation potentiates NMDA receptor-induced depolarization of frog motoneurons ${ }^{14}$. However, the molecular mechanisms underlying the modulation of neuronal activity by $5-\mathrm{HT}_{2 \mathrm{~B}}$ receptors remain elusive.

Membrane proteins, including G protein-coupled receptors (GPCRs), transporters and ionic channels are targeted to specialized membrane domains via interactions with scaffolding proteins. These scaffolding proteins contain multiple protein-protein interaction domains that allow their interaction with a multitude of structural and signaling proteins within large protein networks ${ }^{15}$. Postsynaptic density protein of $95 \mathrm{kDa}$ (PSD95), disc large, zonula occludens-1 (PDZ) domaincontaining proteins constitutes the largest family of scaffolding proteins that allows the formation of microdomains specialized in shaping specific synaptic responses ${ }^{16}$. PDZ domain-containing proteins are not only important for the formation of signaling complexes, but also for synaptic transmission since they contribute to signaling, receptor trafficking, and cytoskeletal 
rearrangements in both presynaptic and postsynaptic elements ${ }^{17,18}$. Several serotonin receptors present PDZ binding domain at their C-terminus, including the three 5- $\mathrm{HT}_{2}$ receptor subtypes (SCV, $\mathrm{SYV} / \mathrm{I}$ and SSV, for 5- $\mathrm{HT}_{2 \mathrm{~A}}, 5-\mathrm{HT}_{2 \mathrm{~B}}$ and 5- $\mathrm{HT}_{2 \mathrm{C}}$ receptor, respectively). The MUlti-PDZ domain Protein-1 (MUPP1) first identified as a partner of 5- $\mathrm{HT}_{2 \mathrm{C}}$ receptor ${ }^{19}$, can also interact with $5-\mathrm{HT}_{2 \mathrm{~A}}$ and 5- $\mathrm{HT}_{2 \mathrm{~B}}$ receptors ${ }^{20}$. The protein associated with Lin-7 (PALS)1 - a tight junction associated protein - gene product INADL (inactivation-no afterpotential D-like) is a paralogue of MUPP1 ${ }^{21}$. By analogy, it was hypothesized that $5-\mathrm{HT}_{2}$ receptors may interact with INADL via PDZ8 ${ }^{22}$. Finally, the 5- $\mathrm{HT}_{2 \mathrm{~A}}$ receptor has been shown to colocalize with PSD-95 and MUPP1 in a subset of dendritic spines of rat cortical pyramidal neurons, and PSD-95 was reported to be necessary to target $5-\mathrm{HT}_{2 \mathrm{~A}}$ and $5-\mathrm{HT}_{2 \mathrm{C}}$ receptors to dendrites of cortical pyramidal neurons ${ }^{23}$ and to increase their turnover in vivo ${ }^{24}$. Other PDZ domain containing proteins associated with $5-\mathrm{HT}_{2 \mathrm{~B}}$ receptors have not yet been described.

Here, we identify a direct interaction between the 5- $\mathrm{HT}_{2 \mathrm{~B}}$ receptor C-terminal PDZ-binding domain (VSYV) and the Channel Interacting PDZ Protein (CIPP, a brain INADL protein isoform) in mouse brain and COS-7 cells. This association potentiates $5-\mathrm{HT}_{2 \mathrm{~B}}$ receptor-dependent signaling in COS-7 cells and primary cultures of hippocampal neurons, probably by preventing $5-\mathrm{HT}_{2 \mathrm{~B}}$ receptor cluster dispersion at the neuronal surface. We also show that the 5- $\mathrm{HT}_{2 \mathrm{~B}}$ receptor, the NMDA receptor, and CIPP can form a signaling platform, which leads to the formation and maturation of dendritic spines, supporting a possible functional role of 5- $\mathrm{HT}_{2 \mathrm{~B}}$ receptor/CIPP interaction in the regulation by serotonin of structural plasticity of glutamatergic synapses. 


\section{Results and Discussion}

Scaffold proteins participate in synaptic multi-protein complexes connecting receptors to downstream signaling pathways ${ }^{25}$. The structure of macromolecular complexes shapes the architecture of the synapse as reviewed in ${ }^{26}$. PDZ proteins are important in synaptic transmission because they contribute to signaling, receptor trafficking, and cytoskeleton rearrangements in the presynaptic and postsynaptic compartments ${ }^{17,18}$. Different PDZ partners of 5- $\mathrm{HT}_{2 \mathrm{~A}}$ and 5-HT $2 \mathrm{C}$ receptors have been identified: $5-\mathrm{HT}_{2 \mathrm{~A}}$ receptors preferentially associate with the PDZ proteins located exclusively at postsynaptic site (e.g. PSD-95, SAP97); 5- $\mathrm{HT}_{2 \mathrm{C}}$ receptors interact with PDZ proteins located at presynaptic and postsynaptic sites such as the Veli3 / CASK / Mint1 complex ${ }^{27}$. In order to delineate the mechanisms through which $5-\mathrm{HT}_{2 \mathrm{~B}}$ receptors may regulate neuronal activity, we investigated putative proteins that associate with $5-\mathrm{HT}_{2 \mathrm{~B}}$ receptors and their functions.

\section{CIPP interacts with the $5-H_{2 B}$ receptor via its PDZ binding domain}

To identify 5- $\mathrm{HT}_{2 \mathrm{~B}}$ receptor associated $\mathrm{PDZ}$ domain interacting proteins, we used its last $14 \mathrm{C}$ terminal amino acids containing a PDZ binding motif as bait in affinity purification from mouse brain coupled to mass spectrometry (AP-MS). These last $14 \mathrm{C}$-terminal amino acids share the common END/EGDKV/TED/EQVSYI/V motif found in human, rat, or mouse 5- $\mathrm{HT}_{2 \mathrm{~B}}$ receptors and not in $5-\mathrm{HT}_{2 \mathrm{~A}}$ or $5-\mathrm{HT}_{2 \mathrm{C}}$ receptors. Two-dimensional (2-D) gel analysis of affinity-retained proteins in experiments using the 5- $\mathrm{HT}_{2 \mathrm{~B}}$ receptor $\mathrm{C}$-terminal peptide as a bait, showed the specific recruitment of a protein of around $70 \mathrm{kDa}$ that appeared as a train of spots on the 2-D gels (Fig. 1A). This train of spots was not observed in experiments using the corresponding peptide lacking the 5$\mathrm{HT}_{2 \mathrm{~B}}$ receptor PDZ binding motif (by introducing a stop codon that deleted of the four C-terminal VSYV residues, or $\triangle \mathrm{PDZ}$ ). The protein corresponding to these spots was identified as CIPP by peptide mass fingerprint (Mascot Score, 153, $\mathrm{p}=8.7 \times 10^{-11}$ ). CIPP corresponds to the brain isoform 3 of the scaffolding protein INADL comprising its last four PDZ domains ${ }^{28}$. Coimmunoprecipitation experiments from COS-7 cells co-expressing Flag-tagged CIPP and HAtagged 5-HT $2 \mathrm{~B}$ receptor followed by Western blotting confirmed the specific association of CIPP with full length 5- $\mathrm{HT}_{2 \mathrm{~B}}$ receptors, which was lost after deletion of the receptor PDZ binding motif $(\triangle \mathrm{PDZ})\left(\right.$ Fig. 1B). In addition to MUPP1, which was identified as a partner of $5-\mathrm{HT}_{2 \mathrm{C}}{ }^{19}, 5-\mathrm{HT}_{2 \mathrm{~A}}$, and 5- $\mathrm{HT}_{2 \mathrm{~B}}$ receptors ${ }^{20}$, CIPP can weakly interact with the C-terminus of 5- $\mathrm{HT}_{2 \mathrm{~A}}$ but not of 5- $\mathrm{HT}_{2 \mathrm{C}}$ receptors ${ }^{27}$. The fact that the CIPP was the most abundant PDZ partner detected in experiments 
performed with $5-\mathrm{HT}_{2 \mathrm{~B}}$ receptor $\mathrm{C}$-terminus suggests high affinity interactions. CIPP was also reported to associate with the PDZ binding site of the NR2 subunit of the NMDA receptor ${ }^{29}$, but also with IRSp53, Cypin, ${ }^{30,31}$, and the acid-sensing ionic channel 3 ASIC $3{ }^{32}$. CIPP may, thus, serve as a scaffold protein that would bring together diverse but functionally connected proteins into close proximity in the neuronal membrane, thus potentiating their signaling.

\section{CIPP increases 5-HT ${ }_{2 B}$ receptor signaling without changing its ligand affinity or Gq-coupling}

To study putative signaling impact, we transiently transfected CIPP and 5- $\mathrm{HT}_{2 \mathrm{~B}}$ receptors in COS7 cells. Using ${ }^{3} \mathrm{H}-$ Mesulergine binding, (a non-selective $5-\mathrm{HT}_{2 \mathrm{~B}}$ receptor antagonist with $\mathrm{Ki}=3 \mathrm{nM}$ ) and RS-127445 competition (a highly selective and potent $5-\mathrm{HT}_{2 \mathrm{~B}}$-receptor antagonist with $\mathrm{Ki}=2$ $\mathrm{nM})^{33}$, we quantified the respective total and surface expression of $5-\mathrm{HT}_{2 \mathrm{~B}}$ receptors in the presence or absence of CIPP. Co-expression of CIPP with the 5-HT $2 \mathrm{~B}$ receptor did not alter the total or membrane expression of the receptor (Fig. 2A). In order to evaluate the effect of CIPP on signal transduction, we stimulated transfected cells with increasing concentrations of a full 5- $\mathrm{HT}_{2 \mathrm{~B}}$ receptor agonist (5-HT) or a partial agonist (DOI) and quantified the amount of inositol phosphate accumulated. Co-expression of CIPP with $5-\mathrm{HT}_{2 \mathrm{~B}}$ receptors increased constitutive $(210 \%$ in the absence of serotonin, and $230 \%$ in the absence of DOI; $p=0.016 ; p=0.029$ ) and stimulated inositol phosphate signaling pathway (200\% for serotonin, and 200\% for DOI; $p=0.029 ; p=0.029$ ) (Fig. 2B). Data were further analyzed using the Black and Leff operational model in order to determine putative change in the power of agonists to activate inositol phosphate production, represented by the $\log \left(\tau / \mathrm{K}_{\mathrm{A}}\right)$ with $\left(\mathrm{K}_{\mathrm{A}}\right)$ as affinity for the receptor and $(\tau)$ its coupling efficacy in activating this particular signaling pathway ${ }^{34,35}$. No difference was found for serotonin in Gq coupling of 5-HT $2 \mathrm{~B}$ receptor $\log \left(\tau / \mathrm{K}_{\mathrm{A}}\right)=7.19 \pm 0.15$, compared to $5-\mathrm{HT}_{2 \mathrm{~B}}$ receptor/CIPP $\log \left(\tau / \mathrm{K}_{\mathrm{A}}\right)=7.13 \pm 0.13$. These results indicate that CIPP neither affects the affinity of 5- $\mathrm{HT}_{2 \mathrm{~B}}$ receptors for Gq proteins nor changes the coupling to the Gq pathway in COS-7 cells (Fig. 2B). Therefore, CIPP increases the level of inositol phosphates in basal condition or upon $5-\mathrm{HT}_{2 \mathrm{~B}}$ receptor stimulation without changing the total or surface expression of the receptor in COS-7 cells.

CIPP gathers $5-H T_{2 B}$ receptors in large clusters on the surface of hippocampal neurons Since CIPP expression potentiates $5-\mathrm{HT}_{2 \mathrm{~B}}$ receptor signal transduction without changing receptor/Gq coupling in COS-7 cells, we tested the hypothesis that CIPP could affect its subcellular 
distribution, using primary cultures of rat hippocampal neurons. First, we verified using RT-qPCR that similar cultures depleted of astrocytes and microglia expressed 5- $\mathrm{HT}_{2 \mathrm{~B}}$ receptors and CIPP mRNA (Fig. 3A). Due to a lack of selective antibody against 5- $\mathrm{HT}_{2 \mathrm{~B}}$ receptor or CIPP, we transfected hippocampal pyramidal neurons with constructs encoding HA- and Flag-tagged 5- $\mathrm{HT}_{2 \mathrm{~B}}$ receptor and CIPP, respectively. We observed that overexpression of the 5- $\mathrm{HT}_{2 \mathrm{~B}}$ receptor was restricted to the somato-dendritic (MAP2-positive and Neurofilament-negative) compartment where it formed clusters, while that of overexpressed CIPP was found in both the somato-dendritic and axonal compartments (Fig. 3B-C).

Indeed, PDZ-domain containing proteins often influence the trafficking of various receptors including GPCRs ${ }^{18}$. In rat cortex, the $5-\mathrm{HT}_{2 \mathrm{~A}}$ receptor colocalizes with PSD-95 and MUPP1 in a subset of dendritic spines of pyramidal neurons, and PSD-95 was reported to be important for 5$\mathrm{HT}_{2 \mathrm{~A}}$ receptor targeting in dendrites of cultured cortical pyramidal neurons ${ }^{23}$. Here, overexpressing CIPP significantly reduced (by $28 \% ; \mathrm{p}<0.0001$ ) the number of $5-\mathrm{HT}_{2 \mathrm{~B}}$ receptor clusters at the plasma membrane while having no effect on the total (surface + intracellular) pool of receptors. This effect of CIPP was accompanied for both total and surface pools of receptors by an increase in the size (by $18 \%$ and $10 \%$, respectively; $\mathrm{p}=0.024$ and $\mathrm{p}=0.034$ ) and intensity (by $26 \%$ and $25 \%$ respectively; $\mathrm{p}=0.0009$ and $\mathrm{p}=0.0003$ ) of $5-\mathrm{HT}_{2 \mathrm{~B}}$ receptor clusters (Fig. 3D-E, Table S1). The fact that CIPP overexpression did not increase the number of clusters of total $5-\mathrm{HT}_{2 \mathrm{~B}}$ receptors and that the increase in size and intensity of these clusters is of similar amplitude than the one of the surface receptors suggests that CIPP effect on receptor clustering was not due to an increased expression of $5-\mathrm{HT}_{2 \mathrm{~B}}$ receptors but rather to a redistribution of the receptors at the cell surface.

We verified that the $\mathrm{C}$-terminal end of the $5-\mathrm{HT}_{2 \mathrm{~B}}$ receptor was involved in its aggregation by transfecting a $5-\mathrm{HT}_{2 \mathrm{~B}}$ receptor deleted for the PDZ binding pattern (5-HT2B $\triangle \mathrm{PDZ}$ ), which blocked the effect of CIPP on the aggregate density of the 5-HT $2 \mathrm{~B}$ receptor (Fig. S1A). Next, we used a TAT-5-HT2B peptide corresponding to the last C-terminal 11 amino acids of the 5- $\mathrm{HT}_{2 \mathrm{~B}}$ receptor that can cross the plasma membrane through the TAT sequence and act as a dominant negative blocking the interaction of the 5- $\mathrm{HT}_{2 \mathrm{~B}}$ receptor with the endogenous CIPP protein. We first verified by Western blot that the TAT-5-HT2B peptide does act as a dominant negative by showing reduced co-immunoprecipitation of CIPP and the 5- $\mathrm{HT}_{2 \mathrm{~B}}$ receptor in the presence of the TAT-5HT2B peptide (SYV) but not in the presence of the mutated TAT-5-HT2B peptide (SSV) (Fig. S1B). Exposure of neurons to the TAT-5-HT2B peptide (SYV) significantly increased (by 33\%; $p$ 
$=0.049$ ) the number of 5- $\mathrm{HT}_{2 \mathrm{~B}}$ receptor clusters at the plasma membrane, while the mutated peptide (SSV) had no effect (Fig. 3F-G). This effect of the TAT-5-HT2B peptide on the number of clusters was accompanied by a decrease in the size (by 38\%; $p=0.0036$ ) and intensity (by 39\%; $p=0.0009$ ) of the 5-HT $2 \mathrm{~B}$ receptor clusters (Fig. 3F-G). We conclude that endogenous CIPP protein can contribute to the formation of $5-\mathrm{HT}_{2 \mathrm{~B}}$ receptor clusters on the surface of pyramidal hippocampal neurons and that overexpressing CIPP further increases the clustering of receptors on the neuronal surface, promoting the formation of larger clusters. This is in agreement with previous work showing the presence of two populations of GPCRs: a population of rapidly diffusing receptors and a second one showing slow diffusion in clusters ${ }^{36}$. CIPP-induced clustering of $5-\mathrm{HT}_{2 \mathrm{~B}}$ receptors may drive intracellular traffic of signaling molecules or partition the membrane into microdomains.

5-HT $T_{2 B}$ receptors aggregate at glutamatergic excitatory synapses regardless of CIPP overexpression

We then determined whether the CIPP-dependent increase in 5- $\mathrm{HT}_{2 \mathrm{~B}}$ receptor clustering occurred in the vicinity of synapses. For this purpose, hippocampal cells were transfected with $\mathrm{HA}-5-\mathrm{HT}_{2 \mathrm{~B}}$ receptor with or without Flag-CIPP and either GFP-Homer1c or Gephyrin FingR-GFP to label excitatory and inhibitory synapses, respectively (Fig. 4A-B). 5- $\mathrm{HT}_{2 \mathrm{~B}}$ receptor clusters were considered at synapses when overlapping with at least 1 pixel of GFP-Homer1c or Gephyrin FingRGFP clusters and extrasynaptic when localized two pixels $(240 \mathrm{~nm})$ away from synaptic markers. We found that $5-\mathrm{HT}_{2 \mathrm{~B}}$ receptor clusters are partially colocalized with synaptic markers and are also located at extrasynaptic sites (Fig. 4A-B). Quantifications revealed the presence of about $40 \%$ of 5 $\mathrm{HT}_{2 \mathrm{~B}}$ receptor clusters at excitatory glutamatergic synapses and this proportion was not affected by CIPP overexpression. Since endogenous CIPP is present in these cultures, it was difficult to conclude whether the presence of CIPP was necessary or not to target the 5- $\mathrm{HT}_{2 \mathrm{~B}}$ receptor at glutamatergic synapses.

Another $\sim 20 \%$ of $5-\mathrm{HT}_{2 \mathrm{~B}}$ receptor clusters were located at inhibitory GABAergic synapses, a percentage slightly increased upon overexpression of CIPP (from 22 to $27 \%$; $=0.021$ ) (Fig. 4CD). This slight increase in the localization of $5-\mathrm{HT}_{2 \mathrm{~B}}$ receptor clusters at inhibitory synapses was observed in parallel with an increase in the number of gephyrin clusters upon CIPP overexpression ( 2.41 vs. 2.93 clusters $/ 100 \mu \mathrm{m}$ ). This means that the overexpression of CIPP does not promote the targeting of $5-\mathrm{HT}_{2 \mathrm{~B}}$ receptors to inhibitory synapses. In addition, $\sim 38 \%$ of $5-\mathrm{HT}_{2 \mathrm{~B}}$ receptor clusters 
were extrasynaptic. Overall, these results indicate that a large proportion of 5- $\mathrm{HT}_{2 \mathrm{~B}}$ receptor clusters is located at glutamatergic synapses in hippocampal neurons regardless of CIPP overexpression. Thus, a function of $5-\mathrm{HT}_{2 \mathrm{~B}}$ receptor may be to tune glutamatergic synapses.

\section{CIPP overexpression prevents the agonist-induced loss of surface 5-HT ${ }_{2 B}$-receptors}

Agonist-induced internalization of certain GPCRs can be controlled by PDZ binding motifs located at their C-terminal tails that mediate their internalization, recycling to the plasma membrane or degradation ${ }^{37}$. For instance, PSD-95 was shown to increase desensitization of the $5-\mathrm{HT}_{2 \mathrm{C}}$ receptormediated $\mathrm{Ca}^{2+}$ responses, while another PDZ protein, MPP3, prevented its desensitization. These contrasting effects of PDZ proteins on the desensitization of the $\mathrm{Ca}^{2+}$ response were correlated with a differential modulation of the cell trafficking of the receptor ${ }^{38}$. We thus explored the putative role of CIPP in the regulation of 5- $\mathrm{HT}_{2 \mathrm{~B}}$ receptor clustering at the neuronal membrane upon agonist receptor stimulation. Neurons overexpressing 5- $\mathrm{HT}_{2 \mathrm{~B}}$ receptors were stimulated with $\mathrm{BW} 723 \mathrm{C} 86$ $(0,50,100,1000 \mathrm{nM})$, a preferential $5-\mathrm{HT}_{2 \mathrm{~B}}$ receptor agonist at these doses ${ }^{33}$ at different time points $(0,10,20 \mathrm{~min})$ after stimulation. The number of clusters of membrane $5-\mathrm{HT}_{2 \mathrm{~B}}$ receptors decreased and their surface area increased as a function of the dose of BW723C86 applied for 20 minutes with a maximum effect at $1 \mu \mathrm{M}$ (Fig. S2A-B). Furthermore, a significant decrease in the number of membrane-associated 5- $\mathrm{HT}_{2 \mathrm{~B}}$ receptor clusters was measured 10 and $20 \mathrm{~min}$ after the onset of agonist application in the absence of CIPP (by 20 and 36\%, respectively; $p=0.0044$ and $p$ $<0.0001$ vs. T0), but no change was detected in the number of clusters in neurons overexpressing CIPP (Fig. 5A-B, Table S1). The surface area and intensity of 5- $\mathrm{HT}_{2 \mathrm{~B}}$ receptor clusters did not change after BW723C86 application in the absence or presence of CIPP overexpression (Fig. 5B). These results indicate that the stimulation of $5-\mathrm{HT}_{2 \mathrm{~B}}$ receptor can decrease the number of its membrane clusters in neurons expressing the receptor in the presence of endogenous CIPP but not in neurons overexpressing CIPP.

Interestingly, the number of $5-\mathrm{HT}_{2 \mathrm{~B}}$ receptor clusters observed after agonist stimulation in neurons overexpressing solely the receptor reached that observed in non-stimulated neurons overexpressing both the receptor and CIPP (Fig. 5B, Table S1). This means that CIPP overexpression decreases the number of $5-\mathrm{HT}_{2 \mathrm{~B}}$ receptor clusters to a level that cannot be further lowered by agonist stimulation. Given that under basal activity conditions, the overexpression of CIPP increases the size and intensity of the $5-\mathrm{HT}_{2 \mathrm{~B}}$ receptor clusters and that stimulation by the 
agonist does not lead to a change in size or intensity of theses clusters, we propose that overexpressing CIPP prevents the agonist-mediated loss of surface $5-\mathrm{HT}_{2 \mathrm{~B}}$ receptors observed in neurons expressing the receptor alone, in the presence endogenous CIPP. The endogenous expression of CIPP is, therefore, sufficient to increase basal activity of the receptor probably by favoring its accumulation within a signaling platform that is saturated upon CIPP overexpression. We propose that CIPP can concentrate $5-\mathrm{HT}_{2 \mathrm{~B}}$ receptors near its effectors on the plasma membrane, thereby increasing its basal signaling independently of receptor stimulation and internalization.

\section{CIPP enhances 5-HT $2 B$ receptor-operated calcium signaling in hippocampal neurons}

If CIPP overexpression prevents agonist-induced loss of 5- $\mathrm{HT}_{2 \mathrm{~B}}$ receptor clusters in neurons, we reasoned that this should strengthen receptor-dependent signal transduction. The activation of the Gq-coupled 5- $\mathrm{HT}_{2}$ receptors increases intracellular $\mathrm{Ca}^{2+}$ levels through inositol trisphosphate receptor (IP3R) activation ${ }^{39,40}$. We thus performed $\mathrm{Ca}^{2+}$ imaging on hippocampal neurons using the fluo-4-AM probe. We measured the intracellular $\mathrm{Ca}^{2+}$ levels in neurons overexpressing CIPP or not, before and after 5- $\mathrm{HT}_{2 \mathrm{~B}}$ receptor stimulation with BW723C86 $(1 \mu \mathrm{M})$. We found that 5- $\mathrm{HT}_{2 \mathrm{~B}}$ receptor stimulation induced a $\mathrm{Ca}^{2+}$ peak in primary dendrites of neurons expressing the receptor alone or in combination with CIPP (Fig. 6A-B). The peak in intracellular $\mathrm{Ca}^{2+}$ level occurred around 5-sec after bath application of the agonist (Fig. 6B). The 5- $\mathrm{HT}_{2 \mathrm{~B}}$ receptor stimulation with BW723C86 increased by $110 \%$ the $\mathrm{Ca}^{2+}$ peak height in neurons expressing the $5-\mathrm{HT}_{2 \mathrm{~B}}$ receptor alone (Fig. 6C). The expression of CIPP further increased the $\mathrm{Ca}^{2+}$ peak height $(136 \%$ of the receptor alone; $\mathrm{p}=0.0056$ ) in neurons co-expressing the $5-\mathrm{HT}_{2 \mathrm{~B}}$ receptor (Fig. 6D), and the area under the curve $(300 \% ; \mathrm{p}<0.0001)$ (Fig. 6D). These results indicate that the overexpression of CIPP potentiates the 5- $\mathrm{HT}_{2 \mathrm{~B}}$ receptor-dependent $\mathrm{Ca}^{2+}$ signaling in hippocampal neurons.

CIPP overexpression or 5-HT $2 B^{-}$-receptor agonist stimulation leads to the dispersal of NMDA receptors associated with $5-H_{2 B}$ receptors

Glutamatergic synapses mediate excitatory neurotransmission in the brain, predominantly through the activation of ionotropic glutamate receptors such as the NMDA receptors. NMDA receptors are part of large protein complexes thanks to their binding to various PDZ domain proteins ${ }^{26}$. The regulation of glutamate receptor clustering and trafficking (insertion/endocytosis) is associated with various forms of synaptic plasticity ${ }^{41}$. It was previously reported that (i) the $5-\mathrm{HT}_{2 \mathrm{~B}}$ receptor co- 
immunoprecipitates with the NR1 subunit of NMDA receptors in frog motoneurons ${ }^{42}$, (ii) a 5- $\mathrm{HT}_{2 \mathrm{~B}}$ receptor agonist facilitates NMDA receptor responses in the presence of the channel blockers MK801 or $\mathrm{Mg}^{2+}$ in motoneurons ${ }^{14}$, (iii) the NMDA receptor channel blocker MK-801 exacerbates behavioral alterations of $H t r 2 b^{-/-}$mice, supporting the notion that the glutamatergic system is to some extent affected by a lack of $5-\mathrm{HT}_{2 \mathrm{~B}}$ receptors ${ }^{11}$, and (iv) CIPP can associates with NMDA receptors ${ }^{29}$. We therefore studied the influence of CIPP and the stimulation of 5- $\mathrm{HT}_{2 \mathrm{~B}}$ receptors on the cellular distribution of the NR1 subunit of the endogenous NMDA receptor in hippocampal neurons.

The overexpression of both the 5- $\mathrm{HT}_{2 \mathrm{~B}}$ receptor and CIPP decreased by $26 \%(\mathrm{p}=0.046)$ the number of NR1 clusters colocalized with $5-\mathrm{HT}_{2 \mathrm{~B}}$ receptor clusters on the neuronal membrane without affecting their size or their intensity in comparison with neurons overexpressing only the 5$\mathrm{HT}_{2 \mathrm{~B}}$ receptor (Fig. 7A-B). Therefore, the overexpression of CIPP impairs the clustering of NMDA receptors associated with $5-\mathrm{HT}_{2 \mathrm{~B}}$ receptors. We then tested putative effect of 5- $\mathrm{HT}_{2 \mathrm{~B}}$ receptor stimulation on NR1 clusters. Activation of 5- $\mathrm{HT}_{2 \mathrm{~B}}$ receptors by BW723C86 (0, 50, 100, $\left.1000 \mathrm{nM}\right)$ in a dose-dependent manner decrease the number of $\mathrm{NR} 1 / 5-\mathrm{HT}_{2 \mathrm{~B}}$ receptor clusters with a maximum of $36 \%(p=0.015)$ at $1 \mu \mathrm{M}$ (Fig. S2B). Stimulation of 5-HT $2 \mathrm{~B}$ receptors by BW723C86 $(1 \mu \mathrm{M})$ for 10 or 20 min significantly reduced (by $35 \%$ and $25 \%$, respectively; $p=0.0035$ and $p=0.0413$ vs. $\mathrm{T} 0$ ) the number of $\mathrm{NR} 1 / 5-\mathrm{HT}_{2 \mathrm{~B}}$ receptor clusters in neurons overexpressing the $5-\mathrm{HT}_{2 \mathrm{~B}}$ receptor alone (Fig. 7B). On the other hand, 5-HT $2 \mathrm{~B}$ receptor stimulation changed neither the size (Fig. 7C), nor the intensity of the remaining NR1/5- $\mathrm{HT}_{2 \mathrm{~B}}$ receptor clusters (Fig. 7D). This means that the decrease in the number of $\mathrm{NR} 1 / 5-\mathrm{HT}_{2 \mathrm{~B}}$ receptor clusters is not the result of a fusion of preexisting clusters and a concentration of NMDA receptors in these clusters but is rather due to their disappearance from these clusters and their dispersion in the membrane. In the presence of CIPP overexpression, 5- $\mathrm{HT}_{2 \mathrm{~B}}$ receptor stimulation had no effect on the number, size, and intensity of $\mathrm{NR} 1 / 5-\mathrm{HT}_{2 \mathrm{~B}}$ receptor clusters (Fig. 7B-D). Thus, the stimulation of the $5-\mathrm{HT}_{2 \mathrm{~B}}$ receptor in the presence of endogenous CIPP induces a reduction in the number of $5-\mathrm{HT}_{2 \mathrm{~B}}$ receptor-associated NR1 clusters, an effect mimicked by the overexpression of CIPP.

Interestingly, the loss of 5- $\mathrm{HT}_{2 \mathrm{~B}}$ receptor clusters induced by the $5-\mathrm{HT}_{2 \mathrm{~B}}$ receptor agonist was observed only for NMDA receptors colocalized with the 5- $\mathrm{HT}_{2 \mathrm{~B}}$ receptor. NR1 clusters that did not colocalize with $5-\mathrm{HT}_{2 \mathrm{~B}}$ receptor clusters (that represented $84.29 \%$ of the total population of NR1 clusters) were not affected by BW723C86 treatment. Indeed, neither the number, the size, nor the 
intensity of NR1 clusters located at a distance from 5- $\mathrm{HT}_{2 \mathrm{~B}}$ receptor clusters were modified by the treatment $(\mathrm{p}=0.36, \mathrm{p}=0.58, \mathrm{p}=0.57$, respectively, $\mathrm{n}=28-25)$, although CIPP overexpression slightly reduced their number (by $21 \%$ ), but not their area or intensity $(p=0.02, p=0.39, p=0.06$, respectively, $n=25-29$ ). These results support that the proximity of the two receptors is necessary for the regulation of NMDA receptor clustering by $5-\mathrm{HT}_{2 \mathrm{~B}}$ receptor signaling. Overall, these results show that activating $5-\mathrm{HT}_{2 \mathrm{~B}}$ receptor or overexpressing CIPP reduce the clustering of NMDA receptors with $5-\mathrm{HT}_{2 \mathrm{~B}}$ receptors.

5-HT $T_{2 B}$ receptor stimulation affects the tripartite complex formed by CIPP, the 5-HT $T_{2 B}$ receptor, and the NMDA receptor

We then determined if the effect of the 5- $\mathrm{HT}_{2 \mathrm{~B}}$ receptor agonist on NR1 clusters was due to changes in interaction of CIPP to its partners. Co-immunoprecipitation experiments in COS-7 cells confirmed that the 5- $\mathrm{HT}_{2 \mathrm{~B}}$ receptor interacts with CIPP and NR1, and can form a macromolecular tripartite complex (Fig. 7E). The 5- $\mathrm{HT}_{2 \mathrm{~B}}$ receptor stimulation by BW723C86 decreased the amount of NR1 co-immunoprecipitated with CIPP or with 5- $\mathrm{HT}_{2 \mathrm{~B}}$ receptors, suggesting reduced association of CIPP to its partners (Fig. 7E). Therefore, activating the 5- $\mathrm{HT}_{2 \mathrm{~B}}$ receptor disperses the macromolecular complex formed by CIPP, the NMDA receptor and the 5- $\mathrm{HT}_{2 \mathrm{~B}}$ receptor. The coimmunoprecipitation of 5- $\mathrm{HT}_{2 \mathrm{~B}}$ receptor with both NR1 and CIPP supports the notion that the NR1 subunit of the NMDA receptor forms a ternary complex with 5- $\mathrm{HT}_{2 \mathrm{~B}}$ receptor and CIPP. This is reminiscent of the ternary complex formed by PSD-95, NR1 and the D1 dopamine receptor ${ }^{43}$. A function of PSD-95 is to interfere with NMDA-D1 receptors coupling independently or not of the cAMP or PKC intracellular signaling cascades ${ }^{43}$. We show here that the overexpression of CIPP or the agonist stimulation of the $5-\mathrm{HT}_{2 \mathrm{~B}}$ receptor decrease the clustering of the NR1 subunit colocalized with 5- $\mathrm{HT}_{2 \mathrm{~B}}$ receptor in hippocampal neurons. It is interesting to note that, in spinal nociceptive Cfibers, 5- $\mathrm{HT}_{2 \mathrm{~B}}$ and NMDA receptor agonists significantly enhanced evoked potentials that were blocked by $\mathrm{PKC} \gamma$ inhibitor peptide or by the $5-\mathrm{HT}_{2 \mathrm{~B}}$ receptor antagonist SB204741. This was associated to the translocation of PKC $\gamma$ to postsynaptic sites and with the phosphorylation of NR1 (pNMDA serine 896) ${ }^{13}$, supporting that it is upon phosphorylation, following stimulation, that NR1 may leave the complex. 
CIPP overexpression or 5-HT $T_{2 B}$ receptor stimulation increases the formation of new dendritic spines and the maturation of a spine subset

The formation of dendritic spines, where excitatory glutamatergic synapses are located, is triggered by a rise in intracellular $\mathrm{Ca}^{2+}$ levels that can be induced upon activation of NMDA receptors, voltage-dependent calcium channels and / or the release of $\mathrm{Ca}^{2+}$ from the endoplasmic stores ${ }^{44}$. Since 5- $\mathrm{HT}_{2 \mathrm{~B}}$ receptors can elevate intracellular levels of $\mathrm{Ca}^{2+}$ from $\mathrm{Ca}^{2+}$ stores ${ }^{39,40}$ and interact with NMDA receptors, we studied the impact of CIPP overexpression or of 5- $\mathrm{HT}_{2 \mathrm{~B}}$ receptor stimulation on the formation and maturation of dendritic spines. CIPP overexpression or 5- $\mathrm{HT}_{2 \mathrm{~B}}$ receptor stimulation affected the density and shape of dendritic protrusions (Fig. 8A). A quantitative analysis showed that overexpressing CIPP, eGFP together with the 5- $\mathrm{HT}_{2 \mathrm{~B}}$ receptor increased by $213 \%$ the overall density of dendritic spines on pyramidal neurons, as compared to cells expressing the $5-\mathrm{HT}_{2 \mathrm{~B}}$ receptor alone $\left(0.79\right.$ spines/ $\mu \mathrm{m}$ for cell expressing only $5-\mathrm{HT}_{2 \mathrm{~B}}$ receptors, compared to 1.70 spines $/ \mu \mathrm{m}$ in presence of CIPP, $\mathrm{p}<0.0001$ ) (Fig. 8B). The classification of the dendritic spines then revealed that overexpressing CIPP and the $5-\mathrm{HT}_{2 \mathrm{~B}}$ receptor increased respectively by $217 \%$ and $276 \%$ the number of filopodia and immature (thin and long thin) spines in comparison with the neurons, which only overexpressed the receptor in the presence of endogenous CIPP ( $p=0.011$ and $\mathrm{p}<0.0001$ ) (Fig. 8C-D). On the other hand, the number of mature dendritic spines (stubby and mushroom types) was not different in neurons overexpressing CIPP or not (3\%, p=0.998), Fig. 8E). We conclude that CIPP overexpression increases the formation of new dendritic spines but has no influence on spine maturation.

We then tested the contribution of $5-\mathrm{HT}_{2 \mathrm{~B}}$ receptor activation with $\mathrm{BW} 723 \mathrm{C} 86$ with or without CIPP in the control of spine density and morphology. In neurons overexpressing the $5-\mathrm{HT}_{2 \mathrm{~B}}$ receptor in the presence of endogenous CIPP, activation of the receptor with BW723C86 $(1 \mu \mathrm{M})$ increased the total number of dendritic spines by $173 \%$ and $179 \%$ after 10 or $20 \mathrm{~min}$ of exposure to the agonist (T0 0.79 spines / $\mu \mathrm{m}, \mathrm{T} 101.38$ spines $/ \mu \mathrm{m}, \mathrm{p}=0.0104$ and T20 1.43 spines $/ \mu \mathrm{m}, \mathrm{p}=$ 0.0041 vs T0) (Fig. 8A-B). We confirmed these findings by performing real-time live recordings of similar neuronal cultures overexpressing $5-\mathrm{HT}_{2 \mathrm{~B}}-\mathrm{HA}$ and $\mathrm{eGFP}$ that were then treated by BW723C86 $(1 \mu \mathrm{M})$ (Fig 8A, Supp Movie). This increase concerned mainly immature dendritic spines of the thin type, which increased by $202 \%$ and $193 \%$ after 10 or 20 min of treatment ( $p=$ 0.0124 and $p=0.0186$, Fig. 8D). The density of mature (stubby and mushroom) spines also significantly increased after exposure to the agonist for $20 \mathrm{~min}(119 \%, \mathrm{p}=0.0029$, Fig. 8E). In 
agreement with a role of the $5-\mathrm{HT}_{2 \mathrm{~B}}$ receptor in the formation and maturation of the spines, the density of filopodia was slightly, although non-significantly, decreased by the agonist $49 \%$ and $34 \%$ after 10 or $20 \mathrm{~min}, \mathrm{p}=0.272$ and $\mathrm{p}=0.103$, Fig. 8C). Therefore, the activation of $5-\mathrm{HT}_{2 \mathrm{~B}}$ receptors leads to spine formation and participates to the maturation of the dendritic spines in neurons expressing solely the receptor.

Unlike neurons overexpressing the 5- $\mathrm{HT}_{2 \mathrm{~B}}$ receptor alone, stimulation with $\mathrm{BW} 723 \mathrm{C} 86$ for 10 or 20 min did not significantly increase the overall population of dendritic spines (T0 1.70, T10 1.96 and T20 1.81 spines / $\mu \mathrm{m}$ ) in neurons overexpressing both CIPP and the receptor (Fig. 8B). However, the 5- $\mathrm{HT}_{2 \mathrm{~B}}$ receptor agonist had an effect on the density of filopodia, which was decreased by $32 \%$ and $40 \%$ after 10 or 20 min-exposures to BW723C86 (T0 vs. T10 p=0.0003, T0 vs. T20 $\mathrm{p}=0.0007$, Fig. 8C). In contrast, the density of immature (T0 vs. T10 p=0.738, T0 vs. T20 p=0.750) and mature (T0 vs. T10 p=0.148, T0 vs T20 p=0.691) spines was unchanged by the treatment (Fig. 8D-E). Therefore, 5- $\mathrm{HT}_{2 \mathrm{~B}}$ receptor stimulation does not enhance the formation and maturation of dendritic spines in neurons overexpressing CIPP.

The comparison of the amount of the diverse categories of spines in neurons overexpressing CIPP at $\mathrm{T} 0$ to that of neurons overexpressing both CIPP and the 5- $\mathrm{HT}_{2 \mathrm{~B}}$ receptor at $\mathrm{T} 20$ showed that the density of immature spines reaches a similar proportion $(\mathrm{p}=0.143)$ (Fig. 8D). Only the proportion of the mature spines was slightly greater in neurons overexpressing the $5-\mathrm{HT}_{2 \mathrm{~B}}$ receptor in the presence of endogenous CIPP after $20 \mathrm{~min}$ of treatment compared to neurons overexpressing both the receptor and CIPP at T0 $(p=0.025)$ (Fig. 8E). This indicates that agonist stimulation has mostly the same effect as CIPP overexpression on spines.

Thus, overexpression of CIPP prevents the agonist-induced loss of 5- $\mathrm{HT}_{2 \mathrm{~B}}$ receptors at the neuronal surface, thereby increasing its activity, leading to a rise in intracellular $\mathrm{Ca}^{2+}$ levels and the formation of dendritic spines. We propose that a function of the NR1/5- $\mathrm{HT}_{2 \mathrm{~B}}$ receptor/CIPP complex could be to potentiate spine formation and maturation through $5-\mathrm{HT}_{2 \mathrm{~B}}$ receptor-mediated activation of IP3R/Ca ${ }^{2+}$ signaling cascades. Similarly, a contribution of $5-\mathrm{HT}_{2 \mathrm{~A}}$ and $5-\mathrm{HT}_{2 \mathrm{C}}$ receptors in controlling dendritic spine structure has been reported. The 5- $\mathrm{HT}_{2 \mathrm{~A}}$ receptor activation was shown to induce an increase in dendritic spine size, as well as phosphorylation of $\mathrm{p} 21$-activated kinase PAK, a downstream target of the neuronal Rac guanine nucleotide exchange factor kalirin-7 involved in spine remodeling ${ }^{45}$. Furthermore, stimulation of 5- $\mathrm{HT}_{2}$ receptors by DOI increased transamidation of Rac1 and Cdc42, but not RhoA in primary cortical cultures, and caused a transient 
dendritic spine enlargement, which can be blocked by Transglutaminases inhibition ${ }^{46}$. PSD-95 interaction has subsequently been shown to drive the targeting of 5- $\mathrm{HT}_{2 \mathrm{~A}}$ and $5-\mathrm{HT}_{2 \mathrm{C}}$ receptors to apical dendrites and to control their turnover in-vivo ${ }^{24}$. Therefore, serotonergic signaling system via the activation of $5-\mathrm{HT}_{2 \mathrm{~A}}, 5-\mathrm{HT}_{2 \mathrm{C}}$ or $5-\mathrm{HT}_{2 \mathrm{~B}}$ receptors (this study) can enhance spine maturation. Spine structural plasticity underlies LTP. The role of the serotoninergic system in the control of LTP has been demonstrated via $5-\mathrm{HT}_{2 \mathrm{~A}}$ receptors ${ }^{47,48}$. Exposure to environmental stressors impairs hippocampal LTP via $5-\mathrm{HT}_{2 \mathrm{C}}$ receptors ${ }^{49}$. In stressed animals, increasing extracellular serotonin concentration by fenfluramine enabled the induction of LTP. This effect can be mimicked by agents that directly activate $5-\mathrm{HT}_{2}$ receptors, including the 5- $\mathrm{HT}_{2 \mathrm{~B}}$ receptor agonist $\mathrm{BW} 723 \mathrm{C} 86$. In addition, fenfluramine prevented the inhibition of LTP caused by the NMDA receptor antagonist D-AP5, suggesting that serotonergic agents are acting on $5-\mathrm{HT}_{2 \mathrm{~B}}$ receptor and NMDA receptordependent mechanisms of LTP ${ }^{12}$, consistent with the present study.

The present data identify CIPP as a scaffolding molecule of the 5- $\mathrm{HT}_{2 \mathrm{~B}}$ receptor at glutamatergic synapses, and suggests a role of the CIPP-5- $\mathrm{HT}_{2 \mathrm{~B}} /$ receptor/NMDA receptor complex in structural plasticity. Further understanding of the function of this complex in vivo is critical to elucidate the contribution of serotonin to synaptic plasticity. 


\section{Materials and Methods}

Plasmid Constructs- cDNAs encoding Human 5-HT $2 \mathrm{~B}$ receptor or mouse 3Flag-CIPP were subcloned into pSG5 mammalian expression vector ${ }^{50}$ or pCAGGS $^{51}$. PCAGGS-3HA-5-HT $2 \mathrm{~B}$ construct was obtained from pCAGGS-5- $\mathrm{HT}_{2 \mathrm{~B}}$ by insertion of a Triple HA tag (YPYDVPDYA) to the N-terminal extremity of $5-\mathrm{HT}_{2 \mathrm{~B}}$ receptors. PCAGGS-3HA-5- $\mathrm{HT}_{2 \mathrm{~B}}-\Delta \mathrm{PDZ}$ was obtained by targeted substitution in order to create stop codon before the PDZ binding site (EEQ*SYV).

The Rattus norvegicus Sprague-Dawley N-methyl-D-aspartate receptor NMDAR1-1a subunit (NR1) complete coding sequence was cloned into PCAGGS-YFP plasmid to generate the Nterminal labeled YFP-NR1 protein.

COS-7 Cell Culture- COS-7 cells were cultured as monolayers in Dulbecco 's modified Eagle 's medium (DMEM) (Glutamax-GIBCO/Invitrogen) supplemented with 10\% fetal calf serum (Biowest SAS) and 1\% penicillin/streptomycin (Sigma-Aldrich), in 9-cm dishes (Falcon/Corning Life Sciences). Cells were incubated at $37{ }^{\circ} \mathrm{C}$ in a $5 \% \mathrm{CO}_{2}$ atmosphere. Cells were $70 \%$ confluent in 6-well plates for inositol phosphate accumulation, in 24-well plates for surface binding and in 9$\mathrm{cm}$ dishes for total binding and co-immunoprecipitation/Western-blot, when they were transfected using the Genjuice transfection reagent (Merck Millipore) in complete DMEM, according to the manufacturer's instructions.

\section{Peptide affinity chromatography and mass spectrometry}

A synthetic peptide comprising the $14 \mathrm{C}$-terminal amino acids of the mouse $5-\mathrm{HT}_{2 \mathrm{~B}}$ receptor and the corresponding peptide lacking the receptor PDZ binding motif (95\% purity, Eurogentec) were coupled via their N-terminal extremities to activated $\mathrm{CH}$-sepharose 4B (GE-Healthcare). Ten $\mu \mathrm{g}$ of each immobilized peptide were incubated with CHAPS-solubilized proteins from mice brain (10 mg per condition) overnight at $4{ }^{\circ} \mathrm{C}$ and affinity-retained proteins were resolved on 2-D gels and detected by silver staining, as previously described ${ }^{27}$. Proteins specifically recruited by the entire peptide, but not the truncated one, were excised, digested in gel using trypsin (Gold, Promega), and the resulting peptides were analyzed using an Ultraflex MALDI-TOF-TOF mass spectrometer (Bruker Daltonik). Analyses were performed in reflectron mode with an accelerating voltage of 25 $\mathrm{kV}$ and a delayed extraction of $50 \mathrm{~ns}$. Spectra were analyzed using the FlexAnalysis software 
(version 2.4, Bruker Daltonik) and auto-proteolysis products of trypsin (mol wt: 842.51, 1045.56, $2211.10,2383.90)$ were used as internal calibrates ${ }^{27}$. Identification of proteins was performed by peptide mass fingerprint using the free Mascot Web server (http://www.matrixscience.com/search_form_select.html) and the SwissProt or NCBIprot databases (containing 16,838 and 172,881 Mus musculus sequences, respectively). The following parameters were used for database interrogation: mass tolerance of $100 \mathrm{ppm}$; fixed chemical modification, carbamidomethylation of cysteines; variable chemical modification, oxidation of methionines; matching peptides with one missed cleavage accepted only when they included two consecutive basic residues or when arginine or lysine residues were followed by one or several acidic residues inside the peptide amino acid sequence.

\section{Co-immunoprecipitation and Western-blotting}

Co-immunoprecipitation and Western-blotting were performed as previously described ${ }^{52}$. COS-7 cells transfected with a total of $10 \mu \mathrm{g}$ of DNA per 9-cm dishes with a ratio of 1:1 (HA-5- $\mathrm{HT}_{2 \mathrm{~B}} /$ empty vector; HA-5-HT ${ }_{2 \mathrm{~B}} \Delta \mathrm{PDZ}$ / empty vector; Flag-CIPP / empty vector HA-5-HT ${ }_{2 \mathrm{~B}}$ / Flag-CIPP; HA-5-HT ${ }_{2 \mathrm{~B}} \Delta \mathrm{PDZ} /$ Flag-CIPP) or 1:1:1 of HA-5-HT ${ }_{2 \mathrm{~B}}$, YFP-NR1, and Flag-CIPP proteins, and maintained in culture for two days before harvesting. Cells were centrifuged and suspended in CHAPS lysis buffer (50 mM Tris-HCl, pH 7.4, 0.05 mM EDTA, 10 mM CHAPS, and protease inhibitor cocktail, $\mathrm{pH} 7.4$ ) and sonicated for $30 \mathrm{~s}$. Cells were next solubilized for $5 \mathrm{~h}$ at $4^{\circ} \mathrm{C}$ under gentle agitation. Lysates were centrifuged $(12,000 \mathrm{xg})$ in order to pellet non-solubilized membranes. Protein concentrations in supernatant were measured using the Pierce ${ }^{\mathrm{TM}}$ Coomassie Protein Assay Kit.

Cell cultures were transduced with a peptide made up of the $11 \mathrm{C}$-terminal residues of the $5-\mathrm{HT}_{2 \mathrm{~B}}$ receptor to competitively occlude the interaction between the receptor's PDZ binding motif and target PDZ proteins. This peptide was N-terminally fused to the transduction domain of the Tat protein from the human immunodeficiency virus type- 1 to allow its intracellular delivery ${ }^{38}$. TAT5-HT2B-C-TER: YGRKKRRQRRRGDKTEEQVSYV; TAT-5-HT2B-C-TER-MUT: YGRKK RRQRRRGDKTEEQVSSV. The TAT-5-HT2B-C-ter peptide was biotinylated. Protein extracts were incubated in the absence or presence of either the TAT-5-HT2B-Cter peptide or the TAT-5HT2B-Cter mutated peptide (10 $\mathrm{mM}$ each). 
Lysates were co-imunoprecipitated with anti-HA, anti-Flag, or anti-NR1 antibody (CST HA-Tag C29F4 Rabbit mAb \#3724, 67 ng/ml; mouse primary antibody against Flag Sigma, $1 \mu \mathrm{g} / \mathrm{ml}$; antiNR1 antibody clone 54.1, Millipore, MAB363, $1.8 \mu \mathrm{g} / \mathrm{ml}$ ) overnight at $4{ }^{\circ} \mathrm{C}$ under gentle agitation. Total lysate and immunoprecipitated proteins were separated by SDS/PAGE onto $10 \%$ acrylamide gels and transferred electrophoretically to nitrocellulose membranes. Inputs represent $5 \%$ of the total protein amount used for immunoprecipitations. Blots were probed with anti-HA $(1: 1,000)$, antiFlag $(1: 1,000)$ or anti-NR1 antibody $(1: 1,000)$ (See Table S2). Anti-mouse and anti-rabbit antibodies $(1: 10,000)$ were used as secondary antibodies. Immunoreactive bands were detected using the Odyssey software. At least three independent experiments were performed.

\section{$\underline{\text { Inositol phosphate accumulation measurement }}$}

Inositol phosphate accumulation was measured according to ${ }^{52}$. COS-7 cells were transfected with a total of $3 \mu \mathrm{g}$ of DNA (1:1 ratio for co-transfection) per 6-well plates. Twenty-four hours later cells were trypsinized (Trypsin 1X $0.05 \%$ EDTA; Invitrogen) and plated in 96-wells plates (30,000 cells/well). The next day, complete medium was replaced by serum-free medium. The day of the experiment, media was replaced by stimulation buffer supplemented with $\mathrm{LiCl}(\mathrm{NaCl} 146 \mathrm{mM}, \mathrm{KCl}$ $4.2 \mathrm{mM}, \mathrm{MgCl}_{2} 0.5 \mathrm{mM}, \mathrm{CaCl}_{2} 1 \mathrm{mM}$, Hepes $10 \mathrm{mM}$, Glucose $5.5 \mathrm{mM}, \mathrm{LiCl} 50 \mathrm{mM}, \mathrm{pH}$ 7.4) to prevent inositol phosphate degradation. Cells were stimulated for two $\mathrm{h}$ at $37^{\circ} \mathrm{C}$ with increasing concentrations $\left(10^{-11}\right.$ to $10^{-5} \mathrm{M}$ in stimulation buffer) of serotonin and DOI (full and partial 5- $\mathrm{HT}_{2 \mathrm{~B}}$ receptor agonists, respectively). The stimulation solution was removed and cells well incubated in the lysis buffer (IP one HTRF Kit, Cisbio) for $1 \mathrm{~h}$. Lysates were distributed in 384-well plates and IP1 was labeled using HTRF reagents. At least three independent experiments were performed in duplicate.

\section{Binding assays}

Binding assays were performed as previously described ${ }^{52}$.

Surface binding. COS-7 cells were transfected with a total of $10 \mu \mathrm{g}$ of DNA per 9-cm dishes using the Genjuice transfectant reagent in complete medium. Twenty-four h later, cells were trypsinized and plated in 24-well plates. The day before experiment, the culture media was replaced by serum 
free media. The day of experiment the media was replaced by Krebs-Ringer-Hepes buffer (130 $\mathrm{mM}$ $\mathrm{NaCl}, 1.3 \mathrm{mM} \mathrm{KCl}, 2.2 \mathrm{mM}, \mathrm{CaCl}_{2}, 1.2 \mathrm{mM} \mathrm{NaH}_{2} \mathrm{PO}_{4}, 1.2 \mathrm{mM} \mathrm{MgSO}$, $10 \mathrm{mM}$ Hepes, $10 \mathrm{mM}$ glucose, $\mathrm{pH}$ 7.4). Cells were incubated with a constant concentration of $\left[{ }^{3} \mathrm{H}\right]-$ Mesulergine $(1 \mathrm{nM})$ and increasing concentrations of RS127445, a selective 5- $\mathrm{HT}_{2 \mathrm{~B}}$ receptor antagonist. RS127445 was diluted in Krebs-Ringer-Hepes buffer at $10^{-11}$ to $10^{-6} \mathrm{M}$ final concentrations. After 90-min incubation at room temperature, cells were washed twice on ice with cold PBS and lysed in SDS $1 \%$ for $1 \mathrm{~h}$. Lysates were transferred in scintillation tubes and $4 \mathrm{ml}$ scintillation cocktail was added to the samples. The radioactivity was counted using a scintillation counter (Beckman Coulter).

Total Binding. COS-7 cells were transfected with a total of $10 \mu \mathrm{g}$ of DNA per 9-cm dishes using the Genjuice transfectant reagent in complete medium. The day after, the complete culture medium was replaced by serum-free medium After two days, cells were scraped on ice, centrifuged for 5 min at $1,000 \mathrm{x} \mathrm{g}$ at $4{ }^{\circ} \mathrm{C}$. Cell pellets were dissociated and lysed in $1 \mathrm{ml}$ of binding buffer $(50 \mathrm{mM}$ Tris $\mathrm{HCl}, 10 \mathrm{mM} \mathrm{MgCl} 2,0.1 \mathrm{mM}$ EDTA, $\mathrm{pH}$ 7.4) and centrifuged for $30 \mathrm{~min}$ at 10,000 x $\mathrm{g}$. Membranes (pellets) were then suspended in $5 \mathrm{ml}$ PBS. Aliquots of membrane suspension (200 $\mu \mathrm{l} /$ well containing $\sim 50 \mu \mathrm{g}$ protein) were distributed in 96 deep well plates. Membranes were incubated at room temperature for $90 \mathrm{~min}$ with $25 \mu \mathrm{l}$ of $\left[{ }^{3} \mathrm{H}\right]$-Mesulergine diluted in binding buffer at a final concentration of $1 \mathrm{nM}$ and $25 \mu \mathrm{l} /$ well of increasing concentrations $\left(10^{-11}-10^{-6} \mathrm{M}\right)$ of RS127445. Membranes were harvested by rapid filtration onto Whatman GF/B glass fiber filters (Brandell-Harvester apparatus) pre-soaked with cold saline solution and washed 3 times with cold saline solution to reduce nonspecific binding. Filters were placed in 6-ml scintillation vials and allowed to dry overnight. The next day, $4 \mathrm{ml}$ of scintillation cocktail were added to the samples. At least three independent experiments were performed in duplicate.

\section{Experimental procedures involving animals.}

All animal procedures were carried out according to the European Community Council directive of 24 November 1986 (86/609/EEC), the guidelines of the French Ministry of Agriculture and the Direction Départementale de la Protection des Populations de Paris (Institut du Fer à Moulin, Animalerie des Rongeurs, license C 72-05-22) and were approved by the local Ethic Committee for Animal Experiments (No. 01170.02). All efforts were made to minimize animal suffering and to reduce the number of animals used. 
$\underline{\text { Hippocampal neuronal culture and transfection. }}$

Hippocampal neurons were prepared from embryonic day 19 Sprague-Dawley rat pups as previously described ${ }^{53,54}$. Dissected tissues were trypsinized $(0.25 \% \mathrm{v} / \mathrm{v})$ and mechanically dissociated in $\mathrm{HBSS}\left(\mathrm{CaCl}_{2} 1.2 \mathrm{mM}, \mathrm{MgCl}_{2} 0.5 \mathrm{mM}, \mathrm{MgSO}_{4} 0.4 \mathrm{mM}, \mathrm{KCl} 5 \mathrm{mM}, \mathrm{KH}_{2} \mathrm{PO}_{4} 0.44\right.$ $\mathrm{mM}, \mathrm{NaHCO}_{3} 4.1 \mathrm{mM}, \mathrm{NaCl} 138 \mathrm{mM}, \mathrm{Na}_{2} \mathrm{HPO}_{4} 0.34 \mathrm{mM}$, D-Glucose $5.5 \mathrm{mM}$ ) containing $10 \mathrm{mM}$ Hepes (Invitrogen). Dissociated cells were plated on glass coverslips (Assistent) precoated with 55 $\mu \mathrm{g} / \mathrm{ml}$ poly-D,L-ornithine (Sigma-Aldrich) in plating medium composed of MEM supplemented with horse serum $(10 \% \mathrm{v} / \mathrm{v}$; Invitrogen), L-glutamine $(2 \mathrm{mM})$, and Na pyruvate ( $1 \mathrm{mM}$, Invitrogen) at a density of $3.4 \times 10^{4}$ cells $/ \mathrm{cm}^{2}$ and maintained in humidified atmosphere containing $5 \% \mathrm{CO}_{2}$ at $37^{\circ} \mathrm{C}$. After attachment for $2-3 \mathrm{~h}$, cells were incubated in maintenance medium that consists of Neurobasal medium supplemented with B27, L-glutamine (2 mM), and antibiotics (Invitrogen). Each week, one-third of the culture medium volume was renewed. For RT-qPCR experiments, cytosine $\beta$-D- arabinofuranoside (AraC) $(5 \mu \mathrm{M})$ was added once at 5 days in vitro (DIV) ${ }^{55}$. Neuronal transfections with plasmids encoding HA-5-HT $2 \mathrm{~B}$, Flag-CIPP, Gephyrin FingR-GFP 56, 57 , Homer1c-GFP ${ }^{58}$ and eGFP were performed at 13-14 DIV using Transfectin (Bio-Rad), according to the instructions of the manufacturer (DNA/lipofectant ratio of 1:3), with $1 \mu \mathrm{g}$ of plasmid DNA per 20-mm well. The following ratio of plasmid DNA was used in co-transfection experiments: 0.5:0.3:0.2 $\mu \mathrm{g}$ (for 5-HT $2 \mathrm{~B}-\mathrm{HA} / \mathrm{CIPP}-F l a g /$ Homer1c-GFP or Gephyrin FingR-GFP or mCherry or eGFP). Experiments were performed 7-10 days after transfection.

\section{$\underline{\text { RT-qPCR }}$}

Total RNAs was extracted using Trizol reagent (Invitrogen) and treated with DNase (Thermoscientific). First-strand cDNA was synthesized by reverse transcription of $2 \mu \mathrm{g}$ of total RNA with Superscript-II reverse transcriptase (Invitrogen, Illkirch, France). Reverse transcriptase was omitted in samples as negative controls. Relative expression levels of mRNAs were determined by real time RT-PCR using Absolute SYBR Green Mix (Thermoscientific) on a QuantStudio apparatus (Applied Biosystems). Efficiency of amplification for each primer pair was checked on a standard curve. Gene expression levels were normalized to rat cyclophilin B (Cyp) mRNA expression. 
The primers used are: Cyp Forward: CCATCGTGTCATCAAGGACTT; Cyp Reverse: TTGCCATCCAGCCAGGAGGTC; Htr2b Forward: GGTGGCTGATTTGCTGGTTG; Htr $2 b$ Reverse: TAGCGATCCAGGGAAATGGC; CIPP Forward: ACCCAGAAGCTGAAGGTTGG; CIPP Reverse: TGGGAGCCTGCAGACATCAT.

\section{$\underline{\text { Immunocytochemistry }}$}

The total (membrane plus intracellular) pools of $5-\mathrm{HT}_{2 \mathrm{~B}}$ receptors were revealed with immunocytochemistry in fixed and permeabilized cells, whereas the membrane pool of 5- $\mathrm{HT}_{2 \mathrm{~B}}-\mathrm{HA}$ was done in non-permeabilized cells. To label the total pool of 5- $\mathrm{HT}_{2 \mathrm{~B}}$ receptors, CIPP or NMDA receptors, cells were fixed for $15 \mathrm{~min}$ at room temperature in paraformaldehyde (PFA; 4\% $\mathrm{w} / \mathrm{v}$; Sigma) and sucrose (20\% w/v; Sigma) solution in PBS. Cells were then washed in PBS, and permeabilized for 4 min with Triton X-100 (0.25\% v/v) in PBS. After washes, nonspecific staining was blocked for $30 \mathrm{~min}$ with bovine serum albumin (BSA; 3\% w/v; Sigma) and goat serum (20\% $\mathrm{v} / \mathrm{v}$; Invitrogen) in PBS. Neurons were then incubated for $1 \mathrm{~h}$ with either the rabbit anti-HA antibody (1:400; Cell Signaling HA-Tag C29F4 Rabbit mAb \#3724) or the mouse anti-Flag antibody (1:400; Sigma) or rabbit anti-Flag antibody (1:400; Sigma) or the mouse anti-NR1 antibody (1:400, clone 54.1, Millipore, MAB363) or anti-MAP2 (Chicken); Abcam; ab5392; dilution 1/500, or Monoclonal mouse anti-Neurofilament, clone RT-97, Millipore, MAB5262; dilution 1/500 in PBS supplemented with Goat Serum (GS) (3\% v/v). CY3 Donkey anti-Chicken $-\operatorname{Ig} \mathrm{Y}++(\operatorname{IgG})(\mathrm{H}+\mathrm{L})$; Jackson; Code703-165-155; dilution 1/500; Cells were then washed three times and incubated for 45 min with Cy5-conjugated donkey anti-mouse antibodies $(1.9 \mu \mathrm{g} / \mathrm{ml}$; Jackson ImmunoResearch) or the Cy3-conjugated goat anti-rabbit antibody $(1.9 \mu \mathrm{g} / \mathrm{ml}$; Jackson ImmunoResearch) in PBS-BSA-goat serum blocking solution, washed, and mounted on slides with mowiol 4-88 (48 mg/ml) (See Table S2). In experiments using BW723C86, the drug was diluted in imaging medium and applied to neurons for 10 or $20 \mathrm{~min}$ at $1 \mu \mathrm{M}$ final concentration. The imaging medium consisted of phenol redfree MEM supplemented with glucose (33 mM), Hepes (20 mM), glutamine (2 mM), Na+-pyruvate (1 $\mathrm{mM})$, and B27 (1X, Invitrogen). Sets of neurons to be compared were labeled and imaged simultaneously. 


\section{$\underline{\text { Fluorescence image acquisition and cluster analyses }}$}

Fluorescence image acquisition and analyses were performed as previously described ${ }^{53,54}$. Images were obtained on a Leica SP5 confocal microscope using the LAS-AF program (Leica). Stacks of 16-35 images were acquired using a $63 \mathrm{X}$ objective with an interval of $0.2 \mu \mathrm{m}$ and an optical zoom of 2. Image exposure time was determined on bright cells to avoid pixel saturation. All images from a given culture were then acquired with the same exposure time.

Quantifications of 5- $\mathrm{HT}_{2 \mathrm{~B}}$ receptor or NMDA receptor clusters were performed using MetaMorph software (Roper Scientific) on projections (sum of intensity) of confocal optical sections. On each cell, a region of interest (ROI) was chosen. For 5- $\mathrm{HT}_{2 \mathrm{~B}}$ receptor or NMDA receptor cluster analyses, images were first flattened background filtered (kernel size, $3 \times 3 \times 2$ ) to enhance cluster outlines, and a user-defined intensity threshold was applied to select clusters and avoid their coalescence. Thresholded clusters were binarized, and binarized regions were outlined and transferred onto raw data to determine the mean 5- $\mathrm{HT}_{2 \mathrm{~B}}$ receptor, CIPP or NMDA receptor cluster number, area and fluorescence intensity. The dendritic surface area of regions of interest was measured to determine the number of clusters per $10 \mu \mathrm{m}^{2}$. For quantifications of $5-\mathrm{HT}_{2 \mathrm{~B}}$ receptor clusters at excitatory or inhibitory synapses, only $5-\mathrm{HT}_{2 \mathrm{~B}}$ receptor clusters comprising at least three pixels and apposed on at least one pixel with GFP-Homer or Gephyrin FingR-GFP clusters were considered. For each culture, we analyzed 7-12 dendrites per experimental condition and $\sim 100$ clusters per dendrites. A total of about 10 neurons were analyzed per condition from two to five independent cultures. The experimenter was blind to the culture treatment.

\section{Calcium imaging acquisition and analyses}

Calcium imaging acquisition and analyses were performed as described in ${ }^{59}$. Neurons expressing $\mathrm{HA}-5-\mathrm{HT}_{2 \mathrm{~B}}$ receptor, mCherry and/or Flag-CIPP were maintained at $37^{\circ} \mathrm{C}$ in a thermostated chamber and superfused with imaging medium preheated at $37^{\circ} \mathrm{C}$. Time-lapse confocal images of neurons were acquired every $500 \mathrm{~ms}$ using an inverted spinning-disc microscope (Leica DMI4000, Yokogawa CS20 spinning Nipkow disk, $63 \times$ objective). At every time point, neurons were illuminated by $491 \mathrm{~nm}$ light from an $\mathrm{Ar} / \mathrm{Kr}$ laser in order to follow cytosolic calcium concentration using Fluo-4AM (Thermofisher). At first and last time point, neurons were illuminated by $561 \mathrm{~nm}$ light to follow eventual morphological changes or displacement artifact. Laser intensity, time of 
illumination and acquisition parameters of the camera remained identical to allow comparison between experiments and bleach correction. In order to analyze calcium concentration change after stimulation with BW723C86 $(1 \mu \mathrm{M})$, ROI were randomly selected in the dendrites of mCherrypositive cells. In addition, ROI were precisely selected out of the mCherry-labeled neurons or other cells in order to identify the background fluorescence. The background intensity was subtracted to the mean intensity values of Fluo-4AM calcium fluorescent probe. Basal intensity of each ROI was determined during the time before injection in order to determine F0 values. Then intensity after stimulation F was normalized by F0 in order to detect and compare each ROI by their specific F/F0. Finally, each ROI were plotted and analyzed using the GraphPad Prism 7 software.

\section{$\underline{\text { Spine analysis }}$}

Quantifications of spine density and shape were performed blind to experimental conditions, on confocal stacks of eGFP images with Imaris (BitPlane, South Windsor, CT, USA). Measurements were made on maximal projection in $\mathrm{z}$ of confocal stacks of 16-35 images acquired with an interval of $0.2 \mu \mathrm{m}$, and an optical zoom of 1.26. Only spines that could be accurately followed over the entire stack were measured. A total of 15-30 dendritic segments were analyzed per condition from two independent cultures. Briefly, dendrites were semi-automatically rebuilt in $3 \mathrm{D}$ and spines automatically segmented using the Filament Tracer tool. Measurements were performed on one dendrite portion per image. Dendrite length, spine length and terminal point diameter data were extracted from Imaris. Dendritic spine densities and classes (stubby, mushroom, thin, and filopodia) were assessed according to ${ }^{60}$. Filopodia were classified as such when their length was $>2 \mu \mathrm{m}$; mushroom spines when the head width was $>0.6 \mu \mathrm{m}$; long-thin spines when their length $>1 \mu \mathrm{m}$; thin spines when their length-to-width ratio (LWR) was $>1$ and stubby spines when their LWR was $<1$.

The spine real-time recordings were realized on living neurons transfected with 5- $\mathrm{HT}_{2 \mathrm{~B}}-\mathrm{HA}$ and eGFP with a Nikon Ti-eclipse microscope, and with an Andor EMCCD 897 camera using a $100 \mathrm{X}$ objective. The neurons were kept, during the experiment, at $37^{\circ} \mathrm{C}$ in the imaging medium. For the images acquisition parameters, an interval of $0.2 \mu \mathrm{m}$ and a stack of $5 \mu \mathrm{m}$ were set. Image exposure time was determined on bright cells to avoid pixel saturation. Pictures were taken every 2 minutes. The three first pictures were acquired before any stimulation then the drug (BW723C86 at 
a final concentration of $1 \mu \mathrm{M}$ ) was applied in the imaging buffer until the end of the experiment (25 minutes in total). The movie and pictures are the maximal projection in $\mathrm{z}$ at each time point.

\section{$\underline{\text { Statistical analyses }}$}

To determine differences between the experimental groups, normal distributions and homoscedasticity were assessed by Shapiro-Wilk's test, D'Agostino \& Pearson's test, and Levene's test, respectively. Putative outliers were determined by the ROUT method and eliminated. For nonparametric test, Mann and Whitney t-test was used for simple comparisons. For parametric test, data were analyzed by one-way ANOVA followed by Holm-Sidak's post-test for multiple comparisons, or by two-way ANOVA followed by Tukey's post-test for multiple comparison. Independent experiments were performed at least 3 times. In all cases, $\mathrm{p}<0.05$ was considered as statistically significant. Means and SEM are represented in all graphs. The statistical tests, indicated in each figure, were performed with the GraphPad Prism 7 software (See Table S3 for full statistical analysis). 


\section{Author information}

\section{Author affiliations:}

${ }^{1}$ INSERM UMR-S 1270, F75005, Paris, France; Sorbonne Université, F75005, Paris; Institut du Fer à Moulin, F75005, Paris.

2 Institut de Génomique Fonctionnelle, Université de Montpellier, CNRS, INSERM, Montpellier, France

\section{Author contributions:}

A. B.*, E. Q.*, I. M., B. C., and M. R., conducted the experiments and analyzed data, P. M., L. M., S. L. designed the experiments, supervised the study, analyzed data, wrote the paper and provided funding, *Equal contributors

Correspondence should be addressed: \#Luc Maroteaux, Email: luc.maroteaux@upmc.fr Tel: 331 458761 23; \#Sabine Levi, Email: sabine.levi@inserm.fr, Tel: 331458761 13, Institut du Fer à Moulin UMR-S 1270 INSERM 17 rue du Fer à Moulin 75005 Paris

Acknowledgments: We thank Dr. D. Choquet for the Homer1c-GFP construct, Dr. A. Triller for the Gephyrin construct, and Mythili Savariradjane, Xavier Marques and the Imaging facility of the IFM. We are indebted to Drs. Michèle Darmon and Anne Roumier for critical reading of the manuscript.

Competing interest: Authors declare no conflict of interest.

Funding: This work has been supported by grants from the Fondation pour la Recherche sur le Cerveau, the Fondation de France, the Fondation pour la Recherche Médicale "Equipe FRM DEQ2014039529", the French Ministry of Research (Agence Nationale pour la Recherche ANR17-CE16-0008 and the Investissements d'Avenir programme ANR-11-IDEX-0004-02). LM and SL teams are part of the École des Neurosciences de Paris Ile-de-France network and of the Bio-Psy Labex and as such this work was supported by French state funds managed by the ANR within the Investissements d'Avenir programme under reference ANR-11-IDEX-0004-02. E. Quentin received a PhD fellowship from the Region Ile de France DIM Cerveau et Pensée. 


\section{Supporting Information.}

The supplementary material includes the summary of the characteristics (in absolute numbers) of 5$\mathrm{HT}_{2 \mathrm{~B}}$ receptor clusters in neurons expressing the receptor alone or in combination with CIPP, the list and references of antibodies used for immunolabeling, and the full statistical analysis of the reported data.

In addition, the quantification of 5- $\mathrm{HT}_{2 \mathrm{~B}}$ receptor clusters in neurons overexpressing CIPP in the presence of 5- $\mathrm{HT}_{2 \mathrm{~B}}$ receptor $\triangle \mathrm{PDZ}$ and the decrease co-immunoprecipitation of CIPP with the 5$\mathrm{HT}_{2 \mathrm{~B}}$ receptor in COS-7 cells expressing the TAT-5- $\mathrm{HT}_{2 \mathrm{~B}}-\mathrm{C}$-ter peptide are presented.

Then, the dose response effect of BW723C86 agonist on 5- $\mathrm{HT}_{2 \mathrm{~B}}$ receptor membrane and NR1associated clusters is displayed in order to confirm the specificity of the agonist effects.

Finally, a movie of real-time live recording of neuronal cultures overexpressing 5-HT2B-HA and eGFP before and after treatment by BW723C $86(1 \mu \mathrm{M})$ illustrates the increase in spine over time. 


\section{References:}

(1) Bevilacqua, L., Doly, S., Kaprio, J., Yuan, Q., Tikkanen, R., Paunio, T., Zhou, Z., Wedenoja, J., Maroteaux, L., Diaz, S., et al. A population-specific HTR2B stop codon predisposes to severe impulsivity, Nature, 2010, 468, 1061-1066.

(2) Bonaventure, P., Guo, H., Tian, B., Liu, X., Bittner, A., Roland, B., Salunga, R., Ma, X. J., Kamme, F., Meurers, B., et al. Nuclei and subnuclei gene expression profiling in mammalian brain, Brain Res, 2002, 943, 38-47.

(3) Duxon, M. S., Flanigan, T. P., Reavley, A. C., Baxter, G. S., Blackburn, T. P., and Fone, K. C. F. Evidence for expression of the 5-hydroxytryptamine-2B receptor protein in the rat central nervous system, Neuroscience, 1997, 76, 323-329.

(4) Choi, D.-S., and Maroteaux, L. Immunohistochemical localisation of the serotonin 5-HT2B receptor in mouse gut, cardiovascular system, and brain, FEBS Lett., 1996, 391, 45-51.

(5) Diaz, S. L., Doly, S., Narboux-Nême, N., Fernandez, S., Mazot, P., Banas, S., Boutourlinsky, K., Moutkine, I., Belmer, A., Roumier, A., et al. 5-HT2B receptors are required for serotoninselective antidepressant actions, Mol Psychiatry, 2012, 17, 154-163.

(6) Belmer, A., Quentin, E., Diaz, S. L., Guiard, B. P., Fernandez, S. P., Doly, S., Banas, S. M., Pitychoutis, P. M., Moutkine, I., Muzerelle, A., et al. Positive regulation of raphe serotonin neurons by serotonin 2B receptors, Neuropsychopharmacology, 2018, 43, 1623-1632.

(7) Doly, S., Quentin, E., Eddine, R., Tolu, S., Fernandez, S., Bertran-Gonzalez, J., Valjent, E., Belmer, A., Viñals, X., Callebert, J., et al. Serotonin 2B receptors in mesoaccumbens dopamine pathway regulate cocaine responses, $J$ Neurosci, 2017, 37, 10372-10388.

(8) Kolodziejczak, M., Bechade, C., Gervasi, N., Irinopoulou, T., Banas, S. M., Cordier, C., Rebsam, A., Roumier, A., and Maroteaux, L. Serotonin modulates developmental microglia via 5-HT2B receptors: potential implication during synaptic refinement of retinogeniculate projections, $A C S$ Chem Neurosci, 2015, 6, 1219-1230.

(9) Montalvo-Ortiz, J. L., Zhou, H., D’Andrea, I., Maroteaux, L., Lori, A., Smith, A., Ressler, K., Nuñez, Y. Z., Farrer, L. A., Zhao, H., et al. Translational studies support a role for serotonin 2B receptors in aggression-related cannabis response, Mol Psychiatry, 2018, 23, 2277-2286.

(10) Lacoste, J., Lamy, S., Ramoz, N., Ballon, N., Jehel, L., Maroteaux, L., and Thibaut, F. A positive association between a polymorphism in the HTR2B gene and cocaine-crack in a French Afro-Caribbean population, World J Biol Psychiatry, 2019, in press, 1-20.

(11) Pitychoutis, P., Belmer, A., Moutkine, I., Adrien, J., and Maroteaux, L. Mice lacking the serotonin Htr2B receptor gene present an antipsychotic-sensitive schizophrenic-like phenotype, Neuropsychopharmacology, 2015, 40, 2764-2773.

(12) Ryan, B. K., Anwyl, R., and Rowan, M. J. 5-HT2 receptor-mediated reversal of the inhibition of hippocampal long-term potentiation by acute inescapable stress, Neuropharmacology, 2008, $55,175-182$.

(13) Aira, Z., Buesa, I., García Del Caño, G., Bilbao, J., Doñate, F., Zimmermann, M., and Azkue, J. J. Transient, 5-HT2B receptor-mediated facilitation in neuropathic pain: Up-regulation of PKC $\gamma$ and engagement of the NMDA receptor in dorsal horn neurons, Pain, 2013, 154, 18651877.

(14) Holohean, A. M., and Hackman, J. C. Mechanisms intrinsic to 5-HT2B receptor-induced potentiation of NMDA receptor responses in frog motoneurones, $\mathrm{Br} J$ Pharmacol, 2004, 143, 351-360. 
(15) Marin, P., Becamel, C., Dumuis, A., and Bockaert, J. 5-HT receptor-associated protein networks: new targets for drug discovery in psychiatric disorders?, Current Drug Targets, 2012, $13,28-52$.

(16) Good, M. C., Zalatan, J. G., and Lim, W. A. Scaffold proteins: hubs for controlling the flow of cellular information, Science, 2011, 332, 680-686.

(17) Dunn, H. A., and Ferguson, S. S. G. PDZ protein regulation of G protein-coupled receptor trafficking and signaling pathways, Mol Pharm, 2015, 88, 624-639.

(18) Feng, W., and Zhang, M. Organization and dynamics of PDZ-domain-related supramodules in the postsynaptic density, Nat Rev Neurosci, 2009, 10, 87-99.

(19) Ullmer, C., Schmuck, K., Figge, A., and Lubbert, H. Cloning and characterization of MUPP1, a novel PDZ domain protein, FEBS Lett, 1998, 424, 63-68.

(20) Becamel, C., Figge, A., Poliak, S., Dumuis, A., Peles, E., Bockaert, J., Lubbert, H., and Ullmer, C. Interaction of serotonin 5-HT2C receptors with PDZ10 of the multi PDZ protein MUPP1, $J$ Biol Chem, 2001, 276, 12974-12982.

(21) Lemmers, C., Médina, E., Delgrossi, M.-H., Michel, D., Arsanto, J.-P., and Le Bivic, A. hINAD1/PATJ, a homolog of discs lost, interacts with crumbs and localizes to tight junctions in human epithelial cells, J Biol Chem, 2002, 277, 25408-25415.

(22) Assémat, E., Crost, E., Ponserre, M., Wijnholds, J., Le Bivic, A., and Massey-Harroche, D. The multi-PDZ domain protein-1 (MUPP-1) expression regulates cellular levels of the PALS1/PATJ polarity complex, Exp Cell Res, 2013, 319, 2514-2525.

(23) Xia, Z., Hufeisen, S. J., Gray, J. A., and Roth, B. L. The PDZ-binding domain is essential for the dendritic targeting of 5-HT2A serotonin receptors in cortical pyramidal neurons in vitro, Neuroscience, 2003, 122, 907-920.

(24) Abbas, A. I., Yadav, P. N., Yao, W.-D., Arbuckle, M. I., Grant, S. G. N., Caron, M. G., and Roth, B. L. PSD-95 is essential for hallucinogen and atypical antipsychotic drug actions at serotonin receptors, $J$ Neurosci, 2009, 29, 7124-7136.

(25) Zeng, M., Chen, X., Guan, D., Xu, J., Wu, H., Tong, P., and Zhang, M. Reconstituted postsynaptic density as a molecular platform for understanding synapse formation and plasticity, Cell, 2018, 174, 1172-1187.e1116.

(26) Frank, R. A., and Grant, S. G. Supramolecular organization of NMDA receptors and the postsynaptic density, Current Opinion in Neurobiology, 2017, 45, 139-147.

(27) Becamel, C., Gavarini, S., Chanrion, B., Alonso, G., Galeotti, N., Dumuis, A., Bockaert, J., and Marin, P. The serotonin 5-HT2A and 5-HT2C receptors interact with specific sets of PDZ proteins, J Biol Chem, 2004, 279, 20257-20266.

(28) Philipp, S., and Flockerzi, V. Molecular characterization of a novel human PDZ domain protein with homology to INAD from Drosophila melanogaster, FEBS letters, 1997, 413, 243-248.

(29) Kurschner, C., Mermelstein, P. G., Holden, W. T., and Surmeier, D. J. CIPP, a novel multivalent PDZ domain protein, selectively interacts with Kir4.0 family members, NMDA receptor subunits, neurexins, and neuroligins, Mol Cell Neurosci, 1998, 11, 161-172.

(30) Alpi, E., Landi, E., Barilari, M., Serresi, M., Salvadori, P., Bachi, A., and Dente, L. Channelinteracting PDZ protein, 'CIPP', interacts with proteins involved in cytoskeletal dynamics, Biochem J, 2009, 419, 289-300.

(31) Barilari, M., and Dente, L. The neuronal proteins CIPP, Cypin and IRSp53 form a tripartite complex mediated by PDZ and SH3 domains, Biological Chemistry, 2010, 391, 1169-1174. 
(32) Anzai, N., Deval, E., Schaefer, L., Friend, V., Lazdunski, M., and Lingueglia, E. The multivalent PDZ domain-containing protein CIPP is a partner of acid-sensing ion channel 3 in sensory neurons, J Biol Chem, 2002, 277, 16655-16661.

(33) Maroteaux, L., Ayme-Dietrich, E., Aubertin-Kirch, G., Banas, S., Quentin, E., Lawson, R., and Monassier, L. New therapeutic opportunities for 5-HT2 receptor ligands, Pharmacol Ther, 2017, 170, 14-36.

(34) Black, J. W., and Leff, P. Operational models of pharmacological agonism, Proc R Soc Lond B Biol Sci, 1983, 220, 141-162.

(35) Kenakin, T., Watson, C., Muniz-Medina, V., Christopoulos, A., and Novick, S. A simple method for quantifying functional selectivity and agonist bias, ACS Chem Neurosci, 2012, 3, 193-203.

(36) Shrivastava, A. N., Rodriguez, P. C., Triller, A., and Renner, M. Dynamic micro-organization of P2X7 receptors revealed by PALM based single particle tracking, Frontiers in Cellular Neuroscience, 2013, 7, 232.

(37) Bahouth, S. W., and Nooh, M. M. Barcoding of GPCR trafficking and signaling through the various trafficking roadmaps by compartmentalized signaling networks, Cellular Signalling, 2017, 36, 42-55.

(38) Gavarini, S., Bécamel, C., Altier, C., Lory, P., Poncet, J., Wijnholds, J., Bockaert, J., and Marin, P. Opposite effects of PSD-95 and MPP3 PDZ proteins on serotonin 5-hydroxytryptamine2C receptor desensitization and membrane stability, Mol Biol Cell, 2006, 17, 4619-4631.

(39) Cox, D. A., and Cohen, M. L. 5-HT2B receptor signaling in the rat stomach fundus: dependence on calcium influx, calcium release and protein kinase C, Behav Brain Res, 1996, 73, 289-292.

(40) Ullmer, C., Boddeke, H. G. W. M., Schmuck, K., and Lübbert, H. 5-HT2B receptor-mediated calcium release from ryanodine-sensitive intracellular stores in human pulmonary artery endothelial cells, Br J Pharmacol, 1996, 117, 1081-1088.

(41) Kellermayer, B., Ferreira, J. S., Dupuis, J., Levet, F., Grillo-Bosch, D., Bard, L., Linarès-Loyez, J., Bouchet, D., Choquet, D., Rusakov, D. A., et al. Differential nanoscale topography and functional role of GluN2-NMDA receptor subtypes at glutamatergic synapses, Neuron, 2018, 100, 106-119.e107.

(42) Bigford, G. E., Chaudhry, N. S., Keane, R. W., and Holohean, A. M. 5-Hydroxytryptamine 5HT2C receptors form a protein complex with N-methyl-D-aspartate GluN2A subunits and activate phosphorylation of Src protein to modulate motoneuronal depolarization, J Biol Chem, 2012, 287, 11049-11059.

(43) Zhang, J., Xu, T.-X., Hallett, P. J., Watanabe, M., Grant, S. G. N., Isacson, O., and Yao, W.D. PSD-95 uncouples dopamine-glutamate interaction in the D1/PSD-95/NMDA receptor complex, J Neurosci, 2009, 29, 2948-2960.

(44) Sabatini, B. L., Oertner, T. G., and Svoboda, K. The life cycle of $\mathrm{Ca}(2+)$ ions in dendritic spines, Neuron, 2002, 33, 439-452.

(45) Jones, K. A., Srivastava, D. P., Allen, J. A., Strachan, R. T., Roth, B. L., and Penzes, P. Rapid modulation of spine morphology by the 5-HT2A serotonin receptor through kalirin-7 signaling, Proc Natl Acad Sci USA, 2009, 106, 19575-19580.

(46) Mi, Z., Si, T., Kapadia, K., Li, Q., and Muma, N. A. Receptor-stimulated transamidation induces activation of $\mathrm{Rac} 1$ and $\mathrm{Cdc} 42$ and the regulation of dendritic spines, Neuropharmacology, 2017, 117, 93-105. 
(47) Wang, R. Y., and Arvanov, V. L. M100907, a highly selective 5-HT2A receptor antagonist and a potential atypical antipsychotic drug, facilitates induction of long-term potentiation in area CA1 of the rat hippocampal slice, Brain Research, 1998, 779, 309-313.

(48) Rozas, C., Loyola, S., Ugarte, G., Zeise, M. L., Reyes-Parada, M., Pancetti, F., Rojas, P., and Morales, B. Acutely applied MDMA enhances long-term potentiation in rat hippocampus involving D1/D5 and 5-HT2 receptors through a polysynaptic mechanism, Eur Neuropsychopharm, 2012, 22, 584-595.

(49) Busceti, C. L., Di Pietro, P., Riozzi, B., Traficante, A., Biagioni, F., Nisticò, R., Fornai, F., Battaglia, G., Nicoletti, F., and Bruno, V. 5-HT(2C) serotonin receptor blockade prevents tau protein hyperphosphorylation and corrects the defect in hippocampal synaptic plasticity caused by a combination of environmental stressors in mice, Pharmacological Research, 2015, 99, 258-268.

(50) Green, S., Issemann, I., and Sheer, E. A versatile in vivo and in vitro eukaryotic expression vector for protein engineering., Nucl. Ac. Res., 1988, 16, 396.

(51) Niwa, H., Yamamura, K., and Miyazaki, J. Efficient selection for high-expression transfectants with a novel eukaryotic vector, Gene, 1991, 108, 193-199.

(52) Moutkine, I., Quentin, E., Guiard, B. P., Maroteaux, L., and Doly, S. Heterodimers of serotonin receptor subtypes 2 are driven by 5-HT2C protomers, J Biol Chem, 2017, 292, 6352-6368.

(53) Gauvain, G., Chamma, I., Chevy, Q., Cabezas, C., Irinopoulou, T., Bodrug, N., Carnaud, M., Levi, S., and Poncer, J. C. The neuronal K-Cl cotransporter KCC2 influences postsynaptic AMPA receptor content and lateral diffusion in dendritic spines, Proc Natl Acad Sci USA, 2011, 108, 15474-15479.

(54) Chamma, I., Heubl, M., Chevy, Q., Renner, M., Moutkine, I., Eugène, E., Poncer, J. C., and Lévi, S. Activity-dependent regulation of the $\mathrm{K} / \mathrm{Cl}$ transporter $\mathrm{KCC} 2$ membrane diffusion, clustering, and function in hippocampal neurons, $J$ Neurosci, 2013, 33, 15488-15503.

(55) Schellekens, H., De Francesco, P. N., Kandil, D., Theeuwes, W. F., Mccarthy, T., van Oeffelen, W. E. P. A., Perelló, M., Giblin, L., Dinan, T. G., and Cryan, J. F. Ghrelin's orexigenic effect is modulated via a serotonin $2 \mathrm{C}$ receptor interaction, ACS Chem Neurosci, 2015, 6, 1186-1197.

(56) Hanus, C., Ehrensperger, M. V., and Triller, A. Activity-dependent movements of postsynaptic scaffolds at inhibitory synapses, $J$ Neurosci, 2006, 26, 4586-4595.

(57) Gross, G. G., Junge, J. A., Mora, R. J., Kwon, H.-B., Olson, C. A., Takahashi, T. T., Liman, E. R., Ellis-Davies, G. C. R., McGee, A. W., Sabatini, B. L., et al. Recombinant probes for visualizing endogenous synaptic proteins in living neurons, Neuron, 2013, 78, 971-985.

(58) Bats, C., Groc, L., and Choquet, D. The interaction between Stargazin and PSD-95 regulates AMPA receptor surface trafficking, Neuron, 2007, 53, 719-734.

(59) Vadodaria, K. C., Mertens, J., Paquola, A., Bardy, C., Li, X., Jappelli, R., Fung, L., Marchetto, M. C., Hamm, M., Gorris, M., et al. Generation of functional human serotonergic neurons from fibroblasts, Mol Psychiatry, 2016, 21, 49-61.

(60) Risher, W. C., Ustunkaya, T., Singh Alvarado, J., and Eroglu, C. Rapid Golgi analysis method for efficient and unbiased classification of dendritic spines, PloS one, 2014, 9, e107591. 


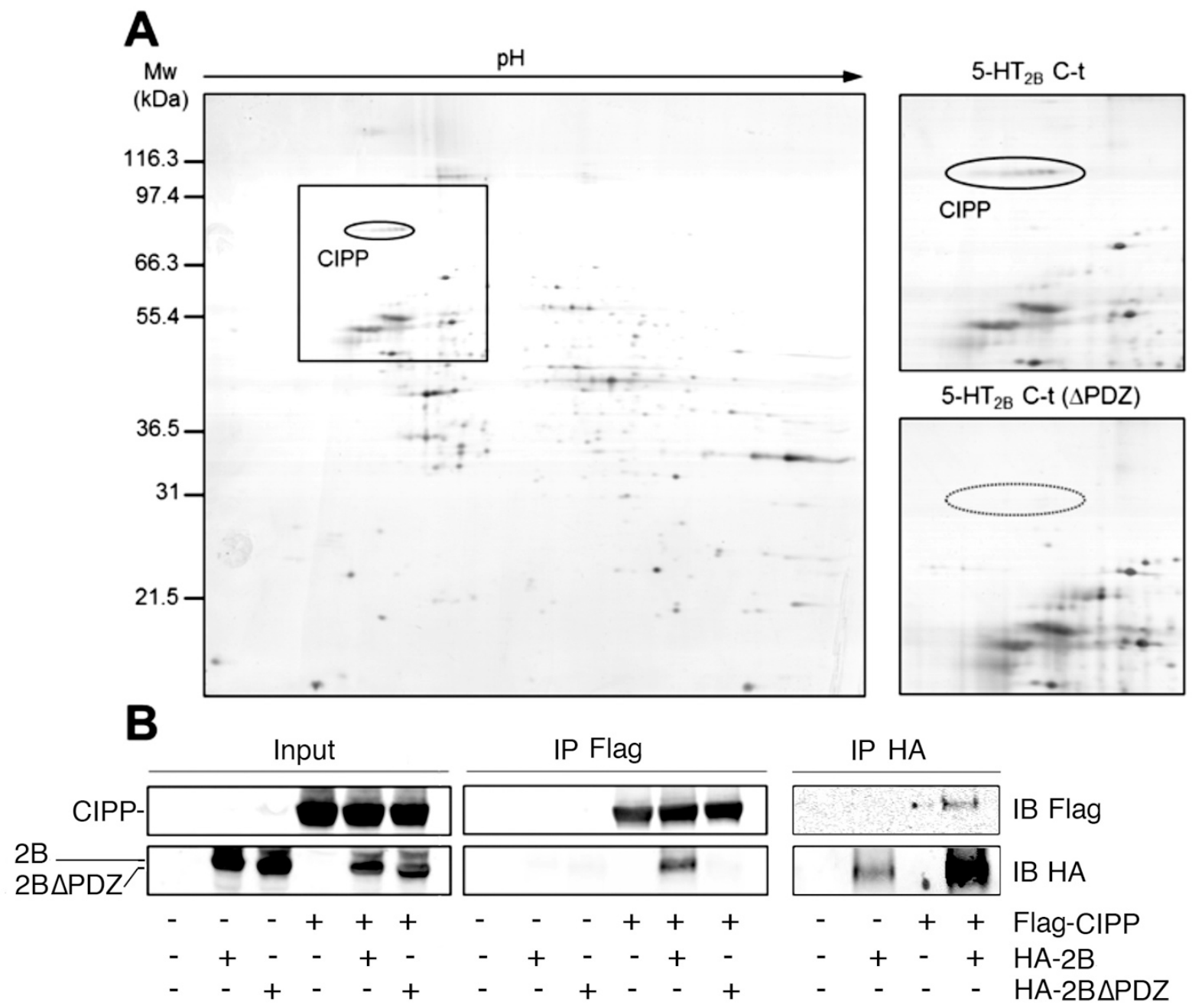

Figure 1 - Interactions between CIPP and the 5-HT $2 \mathrm{~B}$ receptor PDZ binding motif. (A) Pulldown of CIPP by the 5-HT $2 B$ receptor PDZ binding motif. The left panel shows an analytic 2-D gel of pull-down of brain proteins performed with the $5-\mathrm{HT}_{2 \mathrm{~B}}$ receptor C-terminal peptide (last 14 amino-acids) as bait, representative of three independent experiments. The right panels show a magnification of gel region comprising a circled train of protein spots otherwise absent in the corresponding region of $2-\mathrm{D}$ gels obtained with the $5-\mathrm{HT}_{2 \mathrm{~B}}$ receptor $\mathrm{C}$-terminal peptide $(\mathrm{C}-\mathrm{t})$ deleted (last three amino-acids) of the receptor PDZ binding motif ( $\triangle \mathrm{PDZ}$ ). This train of spot was identified as CIPP by MALDI-TOF mass spectrometry (16 out 26 detected peptides matching the CIPP sequence, corresponding to a protein sequence coverage of $25 \%$, Mascot Score 153). (B) Coimmunoprecipitation of CIPP with the 5-HT ${ }_{2 B}$ receptor in COS-7 cells. Proteins from COS-7 cells co-transfected with plasmids coding for HA-tagged 5- $\mathrm{HT}_{2 \mathrm{~B}}$ (HA-2B), HA-tagged 5- $\mathrm{HT}_{2 \mathrm{~B}}-$ $\triangle \mathrm{PDZ}$ (HA-2B $\triangle \mathrm{PDZ}$ ) and/or Flag-tagged CIPP proteins analyzed by Western blotting. Blot of input of proteins revealed by anti-Flag antiserum (IB Flag-CIPP) or by anti-HA antiserum (IB HA-2B) shows the presence of the proteins in each condition (left). Immunoprecipitations using anti-Flag beads (IP Flag-CIPP) or anti-HA beads (IP HA-2B) followed by Western blotting revealed an interaction between CIPP and $5-\mathrm{HT}_{2 \mathrm{~B}}$ receptors but not between CIPP and $5-\mathrm{HT}_{2 \mathrm{~B}}-\Delta \mathrm{PDZ}$ (representative experiment of $\mathrm{n}>3$ independent experiments). 
A

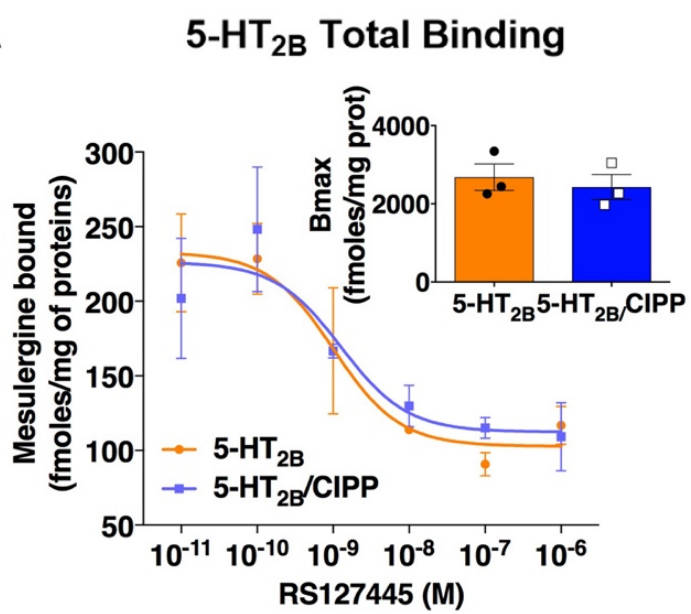

B

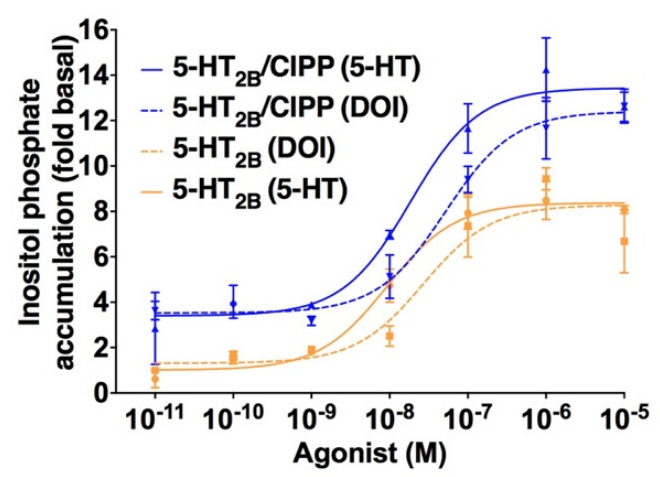

$5-\mathrm{HT}_{2 \mathrm{~B}}$ Surface Binding
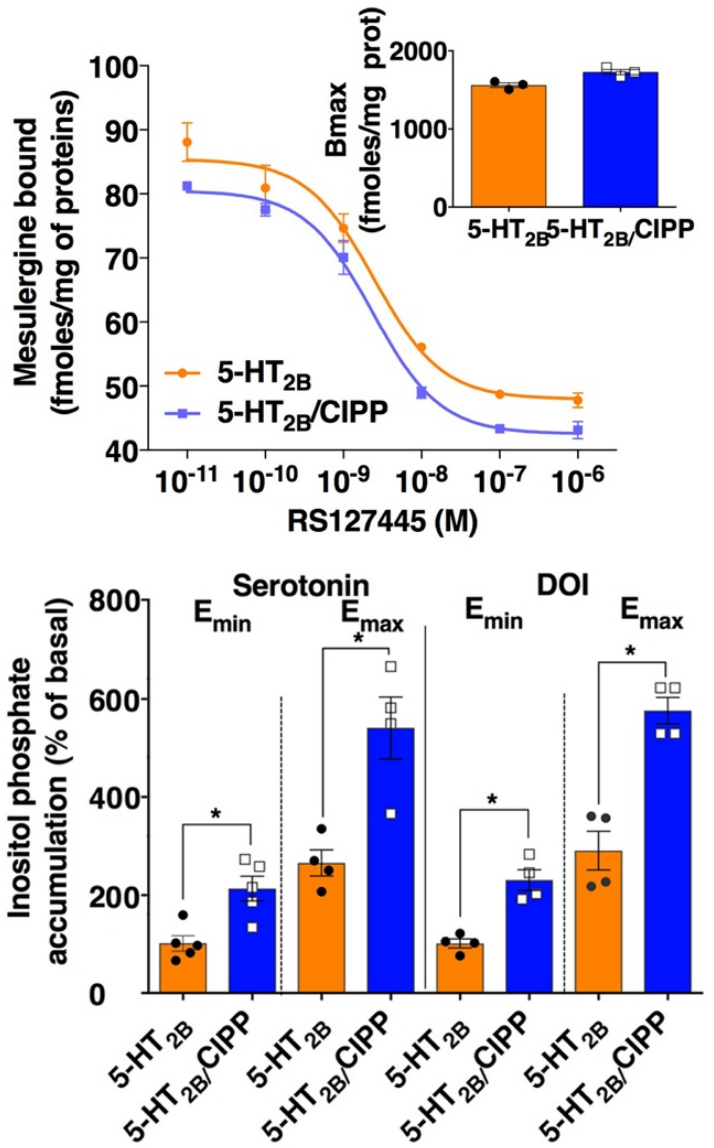

Figure 2 - Impact of CIPP on 5-HT $2 \mathrm{~B}$ receptor expression and signaling. (A) Impact of CIPP on total and cell surface 5-HT ${ }_{2 B}$ receptor expression in COS-7 cells. (left) Radioligand binding competition of tritiated mesulergine performed on membrane proteins from transfected COS-7 cells expressing 5- $\mathrm{HT}_{2 \mathrm{~B}}$ receptors with (Blue square-bars) or without CIPP (Orange circle-bars) showed no different maximal expression of the receptors, which is represented by the Bmax. (Right) Similar experiment performed on living COS-7 cells in order to evaluate $5-\mathrm{HT}_{2 \mathrm{~B}}$ receptor expression at the plasma membrane (surface) showed no different expression $(p>0.05)$. Data were tested using the Mann-Whitney unpaired t-test; $\mathrm{n}=3$ independent experiments, each performed in duplicate. (B) Impact of CIPP on 5-HT ${ }_{2 B}$ receptor-operated signal transduction. (left) The quantification of inositol phosphate production was performed in COS-7 cells expressing 5- $\mathrm{HT}_{2 \mathrm{~B}}$ receptor with or without CIPP and stimulated with increasing concentrations of a full agonist (5-HT) or a partial agonist (DOI) of the receptor. (Right) Co-expression of CIPP with 5-HT $2 \mathrm{~B}$ receptors increased the basal $\left(\mathrm{E}_{\min }, 5-\mathrm{HT} \mathrm{p}=0.0159\right.$, DOI $\left.\mathrm{p}=0.0286\right)$, and stimulated inositol phosphate production $\left(\mathrm{E}_{\max }\right.$, 5 -HT $p=0.0286$, DOI $p=0.0286$ ). Bmax, Emin, Emax were statistically analyzed by MannWhitney unpaired t-test; $n=4-6$ independent experiments, each performed in duplicate. $(* p<0.05)$. 


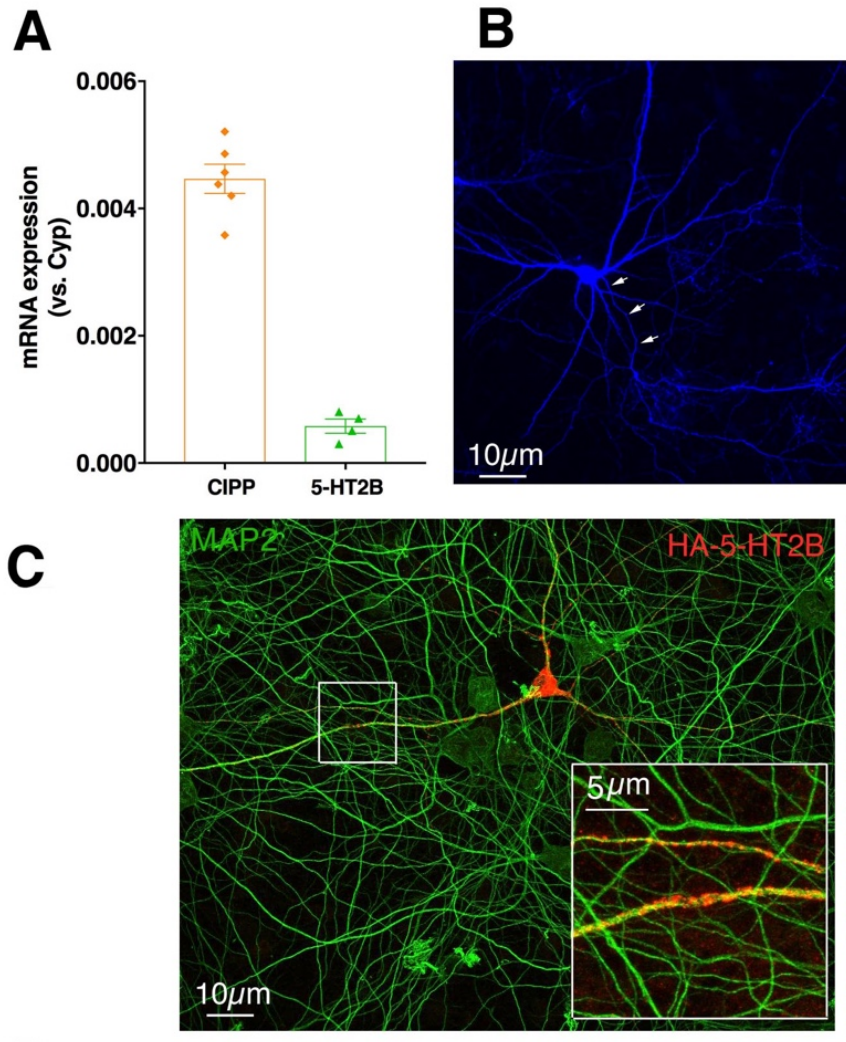

D
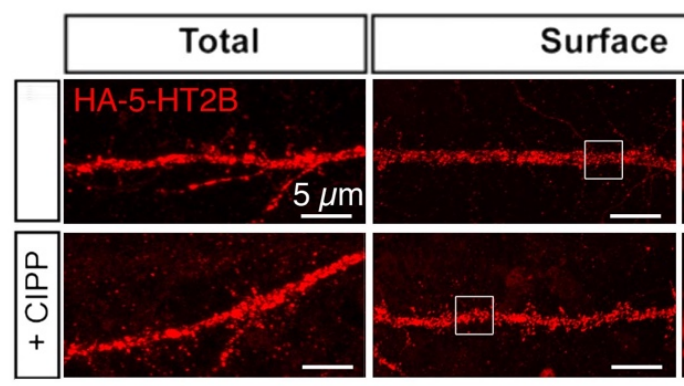

$\mathbf{F}$

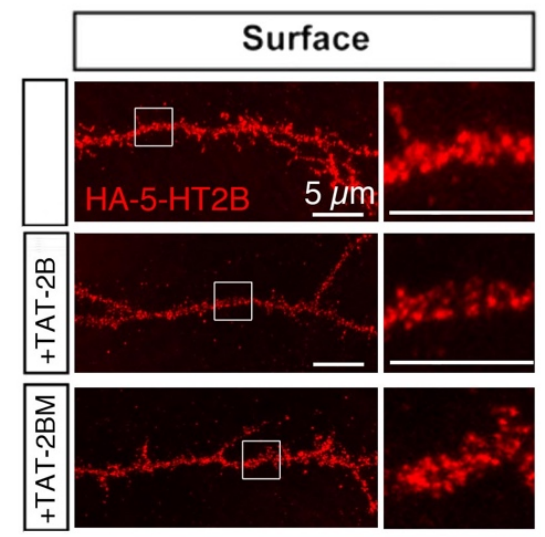

Flag-CIPP
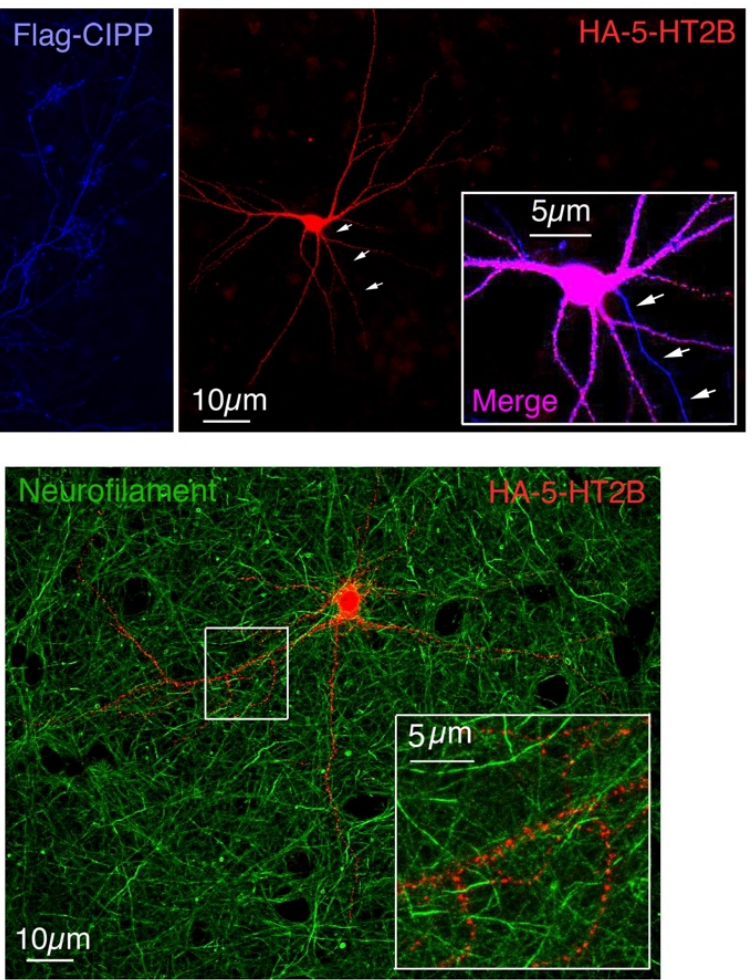

E

$\square$ 5- $\mathrm{HT}_{2 \mathrm{~B}} \square{ }_{5}-\mathrm{HT}_{2 \mathrm{~B}}+\mathrm{CIPP}$

Area Integrated Intensity Total Surface Total Surface Total Surface

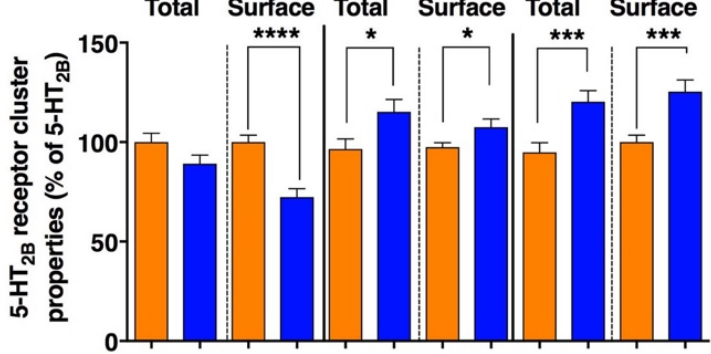

G

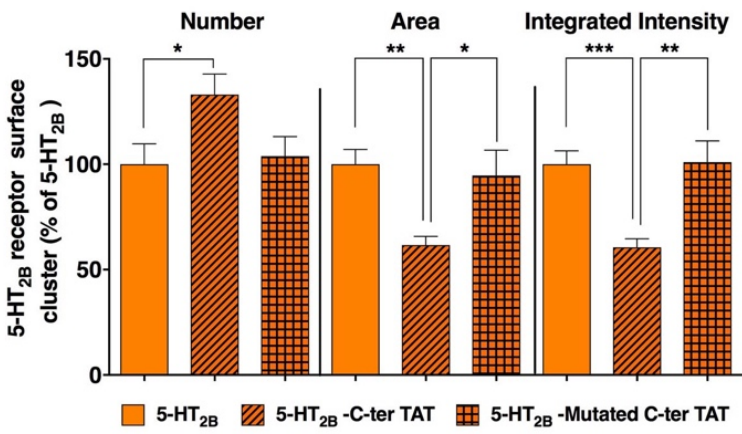


Figure 3 - Impact of CIPP expression on 5-HT $2 \mathrm{~B}$ receptor distribution in hippocampal neurons. (A) Expression of 5-HT $\mathrm{H}_{2 \mathrm{~B}}$ receptors and CIPP mRNA in hippocampal cultures. mRNAs were prepared from cultured hippocampal neurons treated with AraC to eliminate astrocytes and microglia and were quantified by RT-qPCR revealing expression of both CIPP and 5- $\mathrm{HT}_{2 \mathrm{~B}}$ receptor mRNAs in these neurons. (B) Cellular distribution of 5-HT $\mathbf{T}_{2 \mathrm{~B}}$ receptor and CIPP. Primary cultures of hippocampal neurons were transfected with plasmids encoding HA-5$\mathrm{HT}_{2 \mathrm{~B}}$ receptor and Flag-CIPP, and stained for their respective tag. Note the partial overlap in HA5- $\mathrm{HT}_{2 \mathrm{~B}}$ receptor (red) and Flag-CIPP protein (blue) staining in neurons. Inset highlights Flag-CIPP labeling in neurites devoid of 5- $\mathrm{HT}_{2 \mathrm{~B}}$ receptors. Scale bars $10 \mu \mathrm{m}$, inset $5 \mu \mathrm{m}$. (C) Double-labeling of 5-HT ${ }_{2 B}$ receptor (red), and either MAP2 (green, left) or Neurofilament (green, right) to identify respectively somato-dendritic and axonal compartments. The $\mathrm{HA}-5-\mathrm{HT}_{2 \mathrm{~B}}$ receptor (red) is exclusively expressed along MAP2-positive somato-dendritic membrane and excluded from Neurofilament-positive axons . Scale bars $10 \mu \mathrm{m}$, inset $5 \mu \mathrm{m}$. (D) Subcellular distribution of 5$\mathbf{H T}_{2 \mathrm{~B}}$ receptor and CIPP. Morphological analyses were performed on primary cultured hippocampal neurons transfected with a plasmid encoding HA-tagged 5-HT $2 \mathrm{~B}$ receptor together with a plasmid encoding Flag-tagged CIPP or an empty vector (-CIPP). Examples of total (left panel) and surface (right panel) staining of 5- $\mathrm{HT}_{2 \mathrm{~B}}$ receptor (red) in permeabilized and non-permeabilized cells, respectively. Note that $5-\mathrm{HT}_{2 \mathrm{~B}}$ receptors form clusters at the surface of hippocampal dendrites with or without CIPP overexpression (see enlargements, right). Scale bars $5 \mu \mathrm{m}$. (E) Quantification of 5-HT ${ }_{2 B}$ receptor clusters in neurons overexpressing (blue) or not (orange) CIPP. CIPP decreased the number of 5- $\mathrm{HT}_{2 \mathrm{~B}}$ receptor clusters at the neuronal surface $(\mathrm{p}<0.0001)$, but not the total (intracellular + surface) number of clusters $(\mathrm{p}=0.08)$. CIPP increased the size (area) of membrane $(\mathrm{p}=0.034)$ or total (intracellular + membrane) $5-\mathrm{HT}_{2 \mathrm{~B}}$ receptor clusters $(\mathrm{p}=0.024)$. CIPP also increased the density of $5-\mathrm{HT}_{2 \mathrm{~B}}$ receptors per cluster (integrated intensity) for the membrane pool $(p=0.0003)$ and total $(p=0.0009)$. Morphological parameters were analyzed by unpaired t-test, $\mathrm{n}=45-53$ dendrites with 7-12 dendrites per neuron from 5 neuronal cultures. (F) Subcellular distribution of $5-\mathrm{HT}_{2 \mathrm{~B}}$ receptors in neurons expressing TAT-peptides. Morphological analyses were performed on primary cultured hippocampal neurons transfected with a plasmid encoding HA-tagged 5- $\mathrm{HT}_{2 \mathrm{~B}}$ receptor together with $\mathrm{TAT}-5-\mathrm{HT}_{2 \mathrm{~B}}-\mathrm{Cter}$ peptides. Examples of surface staining of 5- $\mathrm{HT}_{2 \mathrm{~B}}$ receptor (red) in non-permeabilized cells. 5- $\mathrm{HT}_{2 \mathrm{~B}}$ receptors form clusters at the surface of dendrites in absence of CIPP overexpression, whose numbers are increased by TAT-5-HT $2 \mathrm{~B}-\mathrm{Cter}$ peptide, but not TAT-5-HT $2 \mathrm{~B}-\mathrm{Cter}$ mutant peptide (see enlargements, right). Scale bars, $5 \mu \mathrm{m}$. (G) Quantification of 5-HT $\mathbf{2 B}_{\mathbf{B}}$ receptor clusters in neurons expressing TAT-peptides. TAT-5- $\mathrm{HT}_{2 \mathrm{~B}}-\mathrm{Cter}$ peptide but not the TAT-5-HT ${ }_{2 \mathrm{~B}}-\mathrm{Cter}$ mutant peptide increased the number of 5-HT $2 \mathrm{~B}$ receptor clusters at the neuronal surface $(\mathrm{p}=0.049)$. TAT-5-HT $2 \mathrm{~B}^{-}$ Cter peptide but not the TAT-5-HT $2 \mathrm{~B}-\mathrm{Cter}$ mutant peptide decreased the size (area) of surface 5$\mathrm{HT}_{2 \mathrm{~B}}$ receptor clusters $(\mathrm{p}=0.0036)$ and the density $(\mathrm{p}=0.0009)$ of $5-\mathrm{HT}_{2 \mathrm{~B}}$ receptors per cluster (integrated intensity). Morphological parameters, expressed as percentage of the basal values, were analyzed by one-way ANOVA and Tukey's multiple comparisons test, $\mathrm{n}=12-18$ dendrites from 2 neuronal cultures $(* * * * \mathrm{p}<0.0001, * * * \mathrm{p}<0.001, * * \mathrm{p}<0.01, * \mathrm{p}<0.05)$. 
A
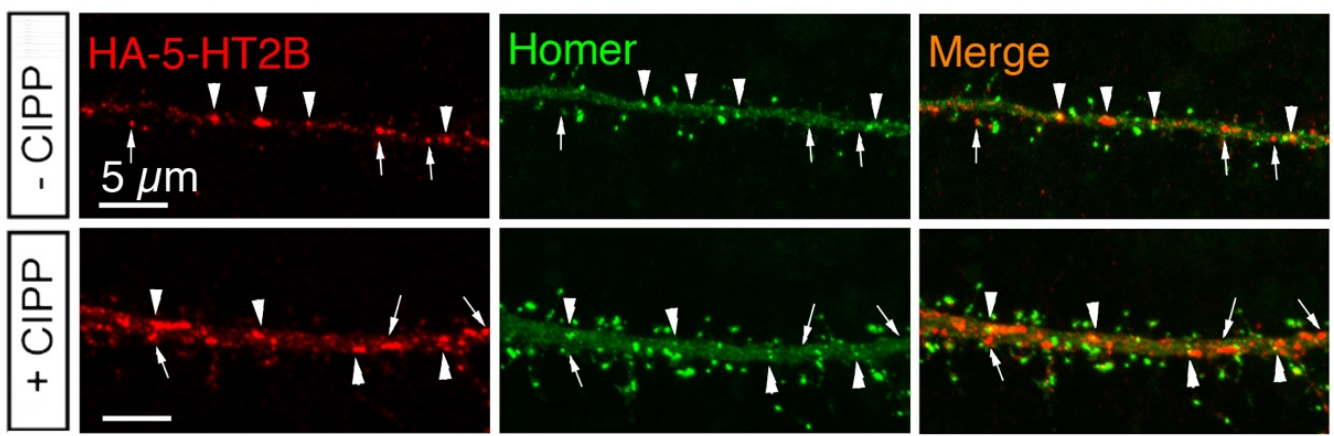

B
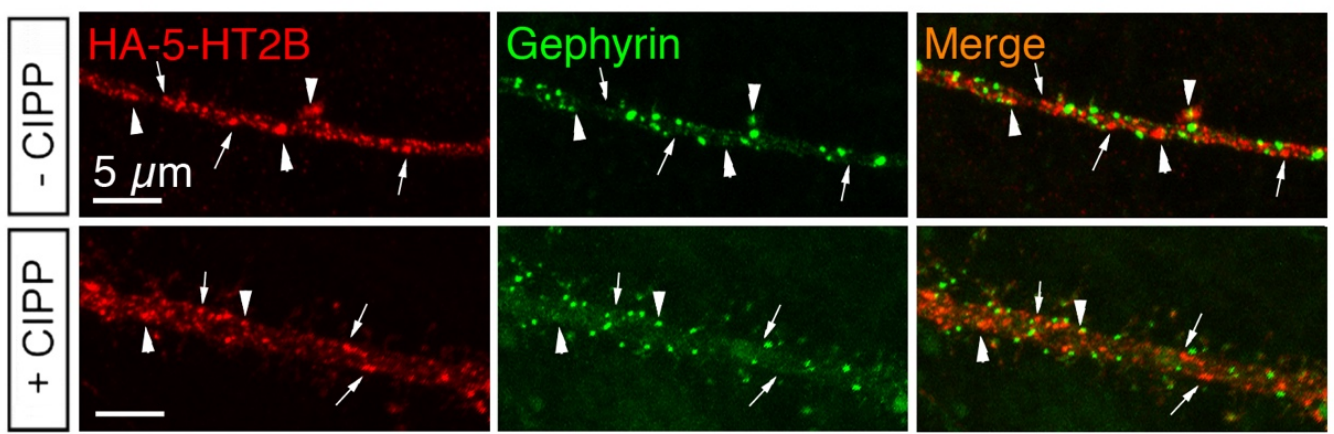

C
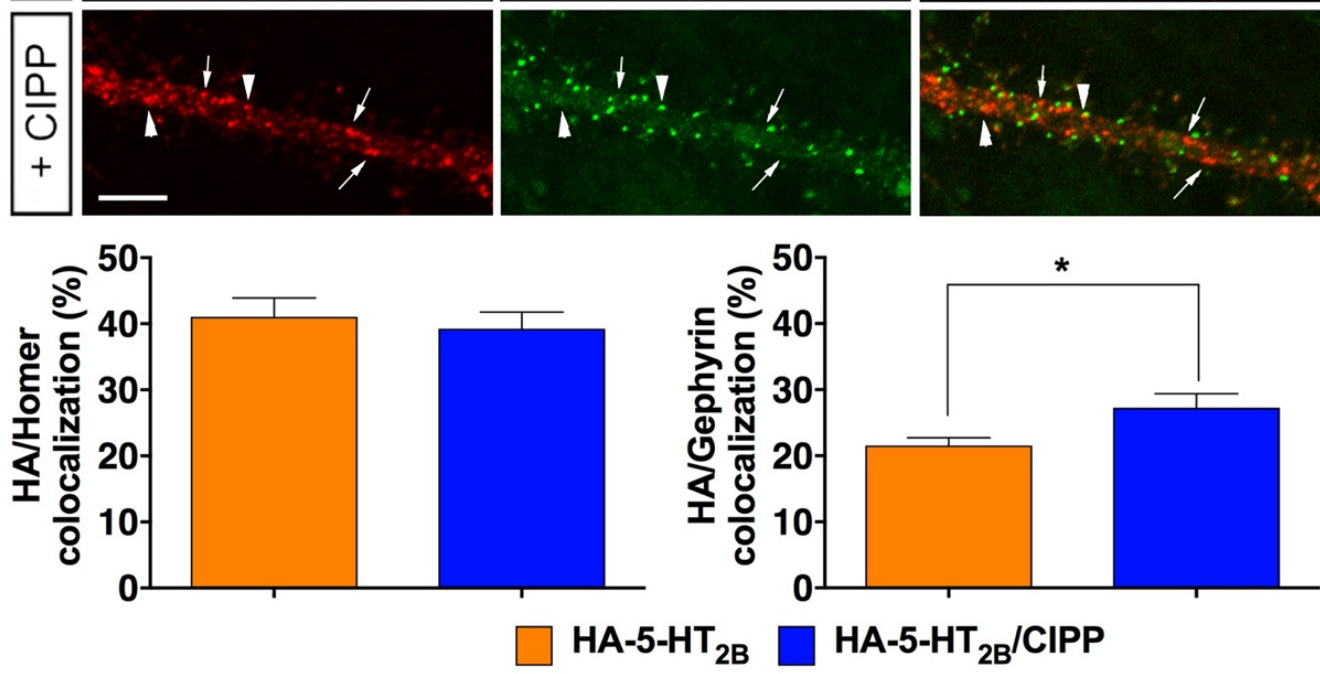

Figure 4 - Contribution of CIPP to 5-HT ${ }_{2 B}$ receptor distribution at excitatory and inhibitory synapses. Neurons were transfected with plasmids encoding $\mathrm{HA}-5-\mathrm{HT}_{2 \mathrm{~B}}$ receptor, Flag-CIPP, and either the glutamatergic or the GABAergic post-synaptic markers GFP-Homer1c or Gephyrin FingR-GFP, and stained for their respective tags. (A-B) Distribution of 5-HT ${ }_{2 B}$ receptor and CIPP at excitatory glutamatergic (A) or inhibitory GABAergic (B) synapses. Note the higher localization (arrowheads) of 5- $\mathrm{HT}_{2 \mathrm{~B}}$ receptor clusters (red) near glutamatergic synapses (green in A) than near inhibitory synapses (green in B) in neurons expressing or not CIPP. Extrasynaptic clusters (small arrows) of 5- $\mathrm{HT}_{2 \mathrm{~B}}$ receptors are detected in dendrites of neurons expressing or not Flag-CIPP. Scale bars $5 \mu \mathrm{m}$. (C) Quantification of the proportion of 5-HT ${ }_{2 B}$ receptor clusters at excitatory or inhibitory synapses. Quantification shows that the $5-\mathrm{HT}_{2 \mathrm{~B}}$ receptor expressed with CIPP (or not) is localized mainly near glutamatergic synapses (left panel). CIPP expression did not change the targeting of the $5-\mathrm{HT}_{2 \mathrm{~B}}$ receptor to excitatory synapses $(\mathrm{p}=0.64)$, but slightly increased receptor targeting to inhibitory synapses (right panel) (Unpaired t-test, 5- $\mathrm{HT}_{2 \mathrm{~B}}$ receptor $+\mathrm{CIPP} v s$. $5-\mathrm{HT}_{2 \mathrm{~B}}$ receptor alone, $\mathrm{n}=25-23$ dendrites; $\mathrm{p}=0.021$ ). Data are from 2 cultures. $* \mathrm{p}<0.05$. 


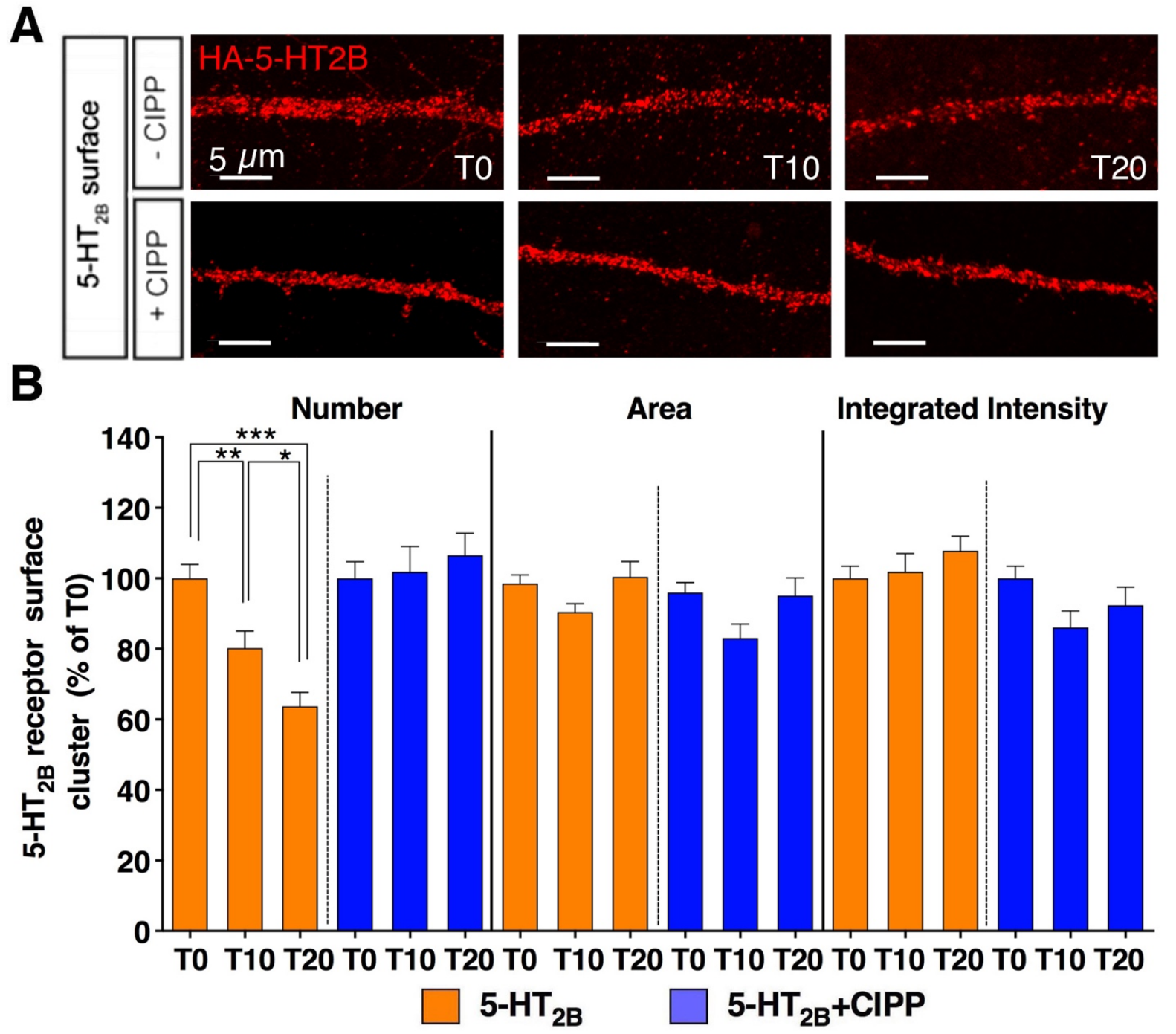

Figure 5 - Effect of CIPP on agonist-induced 5-HT ${ }_{2 B}$ receptor redistribution. (A) $5-\mathrm{HT}_{2 \mathrm{~B}}$ receptor clustering at the dendritic surface 0,10 or $20 \mathrm{~min}$ after BW723C86 stimulation in the absence (top) or presence (bottom) of CIPP. Scale bars $5 \mu \mathrm{m}$. (B) Quantification of 5-HT 2B $_{\text {B }}$ receptor surface clustering following agonist stimulation in the presence (or not) of CIPP. Upon 5-HT $2 \mathrm{~B}$ receptor stimulation by BW723C86 $(1 \mu \mathrm{M})$, the number of 5- $\mathrm{HT}_{2 \mathrm{~B}}$ receptor clusters at the neuronal surface decreased from 0 to $20 \mathrm{~min}$ in the absence but not in the presence of CIPP (T0 vs. T10 $p=0.0044$, T0 vs. T2 $p<0.0001$, T10 vs. T20 $p=0.0192$, number of dendrites $=44-$ 50). The treatment did not change the size (area) and the molecular density (integrated intensity) of $5-\mathrm{HT}_{2 \mathrm{~B}}$ receptor clusters. Data, expressed as percentage of their respective values at $\mathrm{T} 0$, were analyzed by one-way ANOVA and Tukey's multiple comparisons test. Data are from 5 cultures. *** $\mathrm{p}<0.001, * * \mathrm{p}<0.01, * \mathrm{p}<0.05$. 

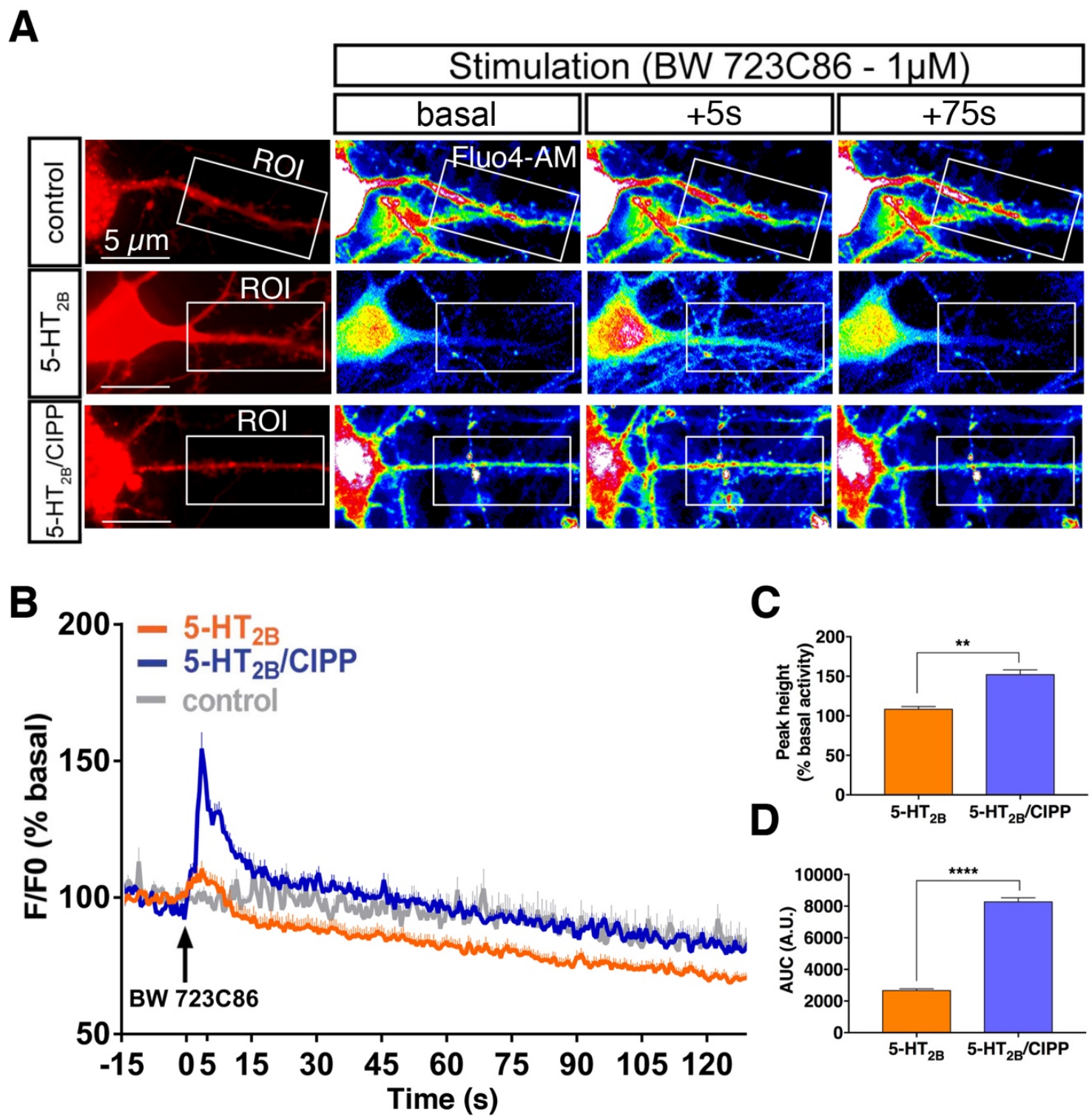

Figure 6 - Effect of CIPP on 5-HT $2 \mathrm{~B}$ receptor-operated calcium signaling in hippocampal neurons. (A) The top panels show examples of selected images of mCherry (left) and Fluo4-AM recordings (right) with ROIs (white boxes) at T0 (basal), T5, and T75 s of BW723C86 stimulation of neurons expressing mCherry (control), or HA-5-HT $2 \mathrm{~B}$ receptor alone, or co-expressing HA-5$\mathrm{HT}_{2 \mathrm{~B}}$ receptor and Flag-CIPP. Scale bars $5 \mu \mathrm{m}$. (B) Summed calcium transients were recorded in hippocampal cells transfected with constructs encoding mCherry (control, grey line), mCherry and $5-\mathrm{HT}_{2 \mathrm{~B}}$ receptor (orange line), or 5- $\mathrm{HT}_{2 \mathrm{~B}}$ receptor and CIPP (blue line). The curves were obtained from 3-4 independent experiments, averaging at least 49 individual ROI measurements. The arrow indicates the beginning (T0) of BW723C86 stimulation $(1 \mu \mathrm{M})$. (C) The histogram shows the increased height of the peak $\left(\mathrm{F} / \mathrm{F}_{0}\right)$ in percent of basal activity for the 5- $\mathrm{HT}_{2 \mathrm{~B}}$ receptor co-expressed with CIPP ( $p=0.0056, n=133$ and $n=230$ ROI). (D) The histogram shows the increased area under the curve (AUC) in arbitrary units (A.U.) for the 5-HT $2 \mathrm{~B}$ receptor co-expressed with CIPP. $(\mathrm{p}<0.0001, \mathrm{n}=49$ and $\mathrm{n}=143 \mathrm{ROI})$. Data were analyzed by Mann-Whitney unpaired t-test). Data are from 10-50 neurons from 3-4 neuronal cultures. ${ }^{* * * *} \mathrm{p}<0.0001, * * \mathrm{p}<0.01$ 


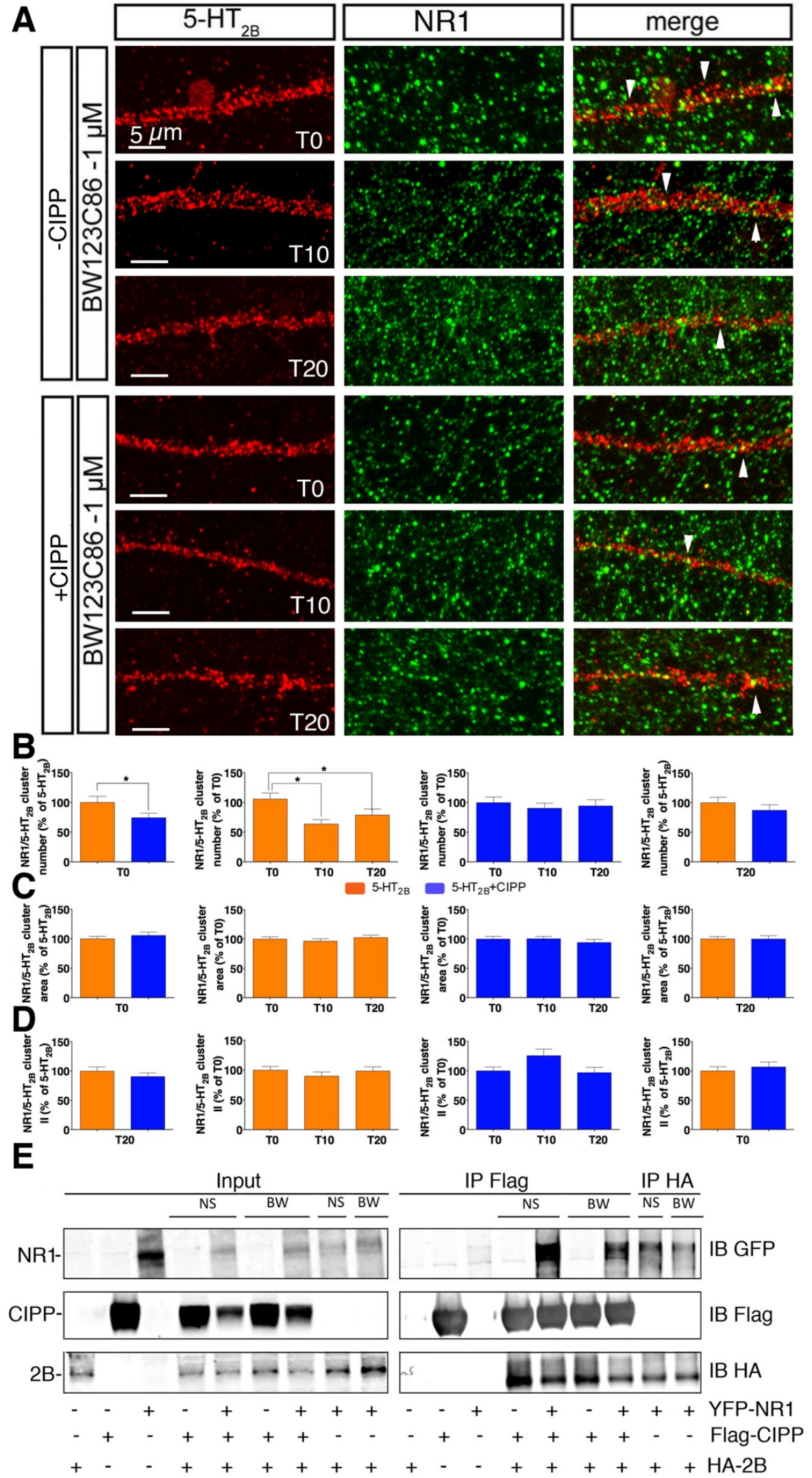


Figure $7-5-\mathrm{HT}_{2 \mathrm{~B}}$ receptor stimulation induces a cellular redistribution of the complex formed by CIPP, the NMDA receptor and the 5-HT $2 \mathrm{~B}$ receptor. (A) Effect of CIPP on NMDA receptor clustering upon 5-HT $2 \mathrm{~B}$ receptor stimulation. Examples of clusters of HA-tagged 5- $\mathrm{HT}_{2 \mathrm{~B}}$ receptor (red) and endogenous NR1 subunit of the NMDA receptor (green) in the absence (top) or presence (bottom) of Flag-tagged CIPP at different time points after BW723C86 $(1 \mu \mathrm{M})$ application. Note the decrease in the density of NR1 clusters (arrowheads) in the absence but not in the presence of CIPP after $10 \mathrm{~min}$ of treatment that persists up to $20 \mathrm{~min}$. Scale bars $5 \mu \mathrm{m}$. (B) Quantification of the number of NR1 clusters colocalized with 5-HT $2 \mathrm{~B}$ receptor clusters in neurons overexpressing HA-tagged 5- $\mathrm{HT}_{2 \mathrm{~B}}$ receptors alone (orange bars) or 5- $\mathrm{HT}_{2 \mathrm{~B}}$ receptors and CIPP (blue bars). In basal activity condition (T0), the expression of CIPP decreased the number of NR1 clusters colocalized with those of 5- $\mathrm{HT}_{2 \mathrm{~B}}$ receptors $\left(\mathrm{CIPP}+5-\mathrm{HT}_{2 \mathrm{~B}}\right.$ receptor $v$ s. $5-\mathrm{HT}_{2 \mathrm{~B}}$ receptor alone, $\mathrm{p}=0.046$, number of cells $=28-27)$. Stimulation of 5- $\mathrm{HT}_{2 \mathrm{~B}}$ receptors for 10 or 20 min significantly reduced the number of NR1 clusters co-localized with $5-\mathrm{HT}_{2 \mathrm{~B}}$ receptor clusters in the absence of CIPP (T0 vs. T10 p = 0.0035 , T0 vs. T20 p $=0.0413$, number of cells $=26-28$ ) but not in its presence. Note that after a 20-min exposure to BW723C 86 , the number of NR1 clusters co-localized with the 5- $\mathrm{HT}_{2 \mathrm{~B}}$ receptor is the same in neurons expressing the receptor alone or in combination with CIPP. (C-D) Quantification showing no effect of CIPP expression or BW723C86 on the size (C) and intensity (D) of NR1 clusters colocalized with $5-\mathrm{HT}_{2 \mathrm{~B}}$ receptor clusters in neurons overexpressing the receptor alone (orange bars) or together with CIPP (blue bars). B-D: Data (expressed as percent of $\mathrm{T} 0$ or of $5-\mathrm{HT}_{2 \mathrm{~B}}$ receptor expressed alone) were statistically analyzed by one-way ANOVA and Holm-Sidak's multiple comparisons test; $\mathrm{n}$ of dendrites $=22-28$ from 3 independent cultures; * $\mathrm{p}<0.05$. (E) Co-immunoprecipitation of CIPP, NR1 and 5-HT $2 \mathrm{~B}$ receptor. Proteins from COS-7 cells co-transfected with plasmids coding for HA-5-HT $2 \mathrm{~B}$ receptor (HA-2B), YFP-NR1, and/or Flag-CIPP were analyzed by Western blotting. (left) Blots of input of proteins revealed by anti-Flag (IB Flag-CIPP), anti-GFP (IB YFP-NR1) or anti-HA (IB HA-2B) antibodies show the presence of the proteins in the control non-stimulated (NS) condition and upon BW723C86 (BW) stimulation. (right) Proteins immunoprecipitated by anti-Flag (IP Flag) or antiHA (IP HA-2B) beads and revealed with either anti-Flag (IB Flag-CIPP), anti-GFP (IB YFP-NR1), or anti-HA (IB HA-2B) antibody showed the existence of a tripartite complex. Note the reduced amount of NR1 co-immunoprecipitated with the 5-HT $2 \mathrm{~B}$ receptor upon BW723C86 stimulation. Representative blot from 3 independent experiments. 
A
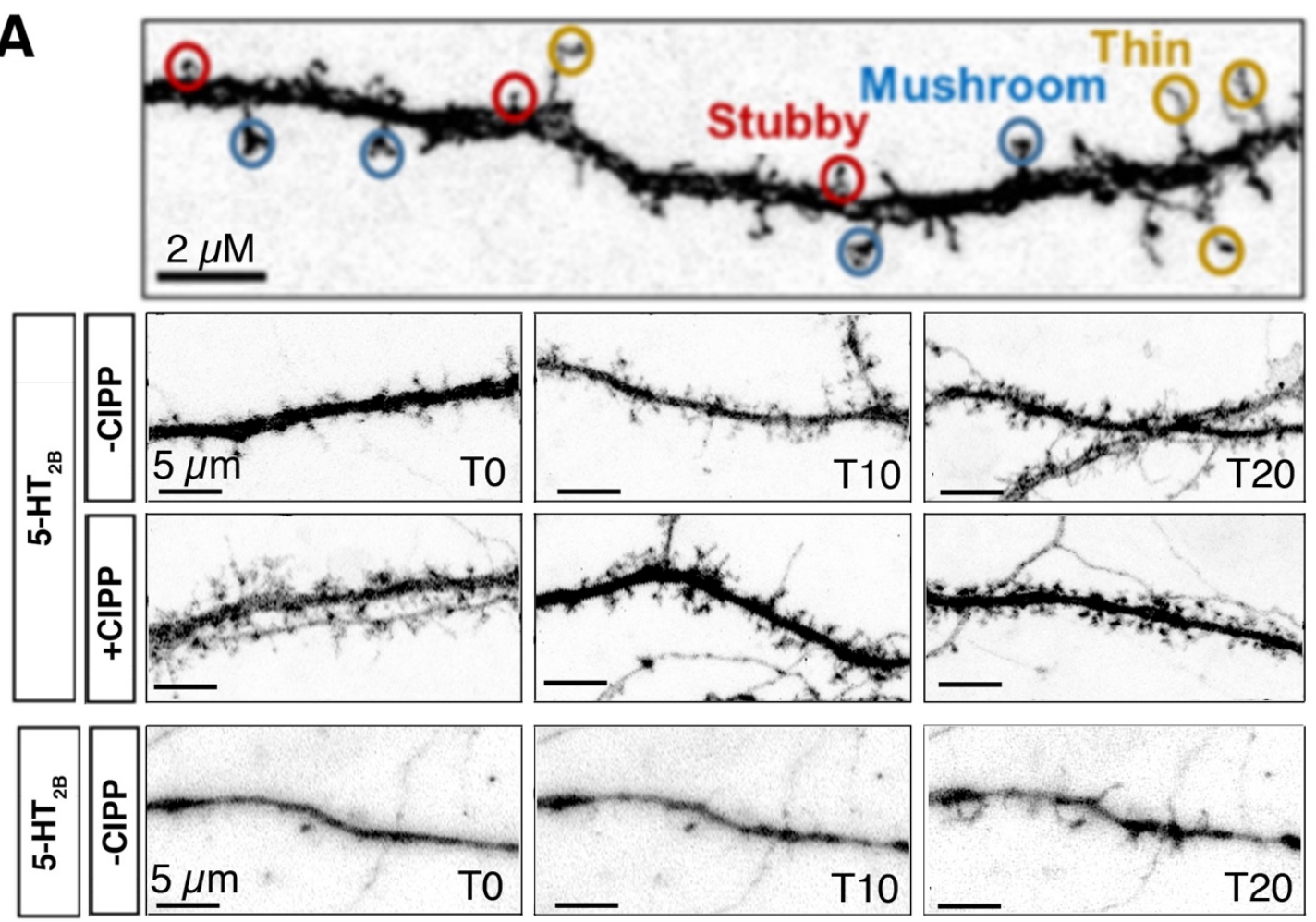

B

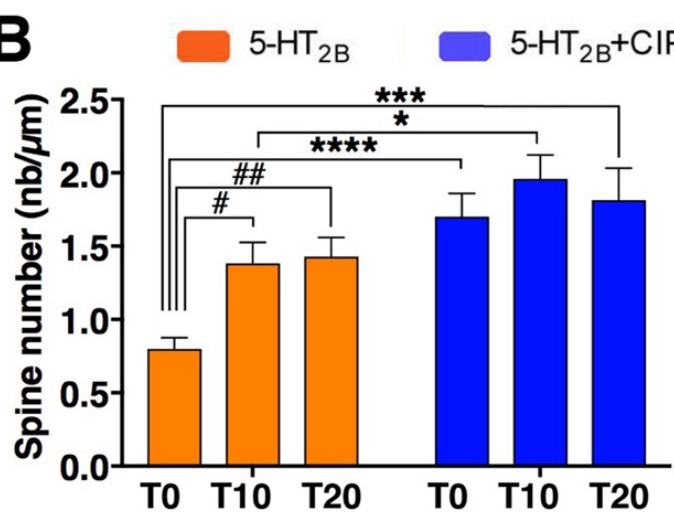

D

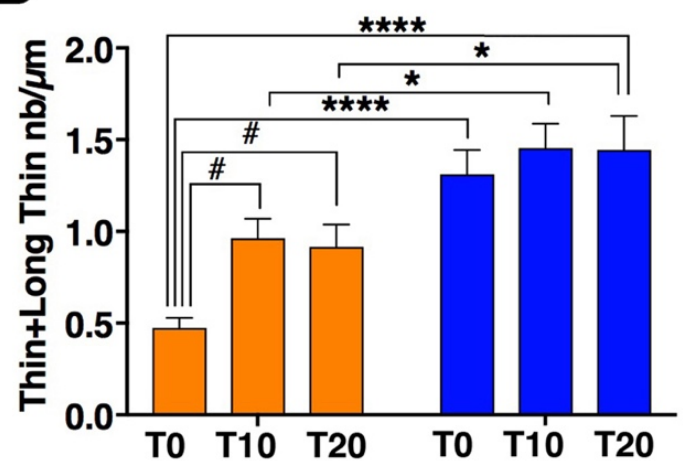

C

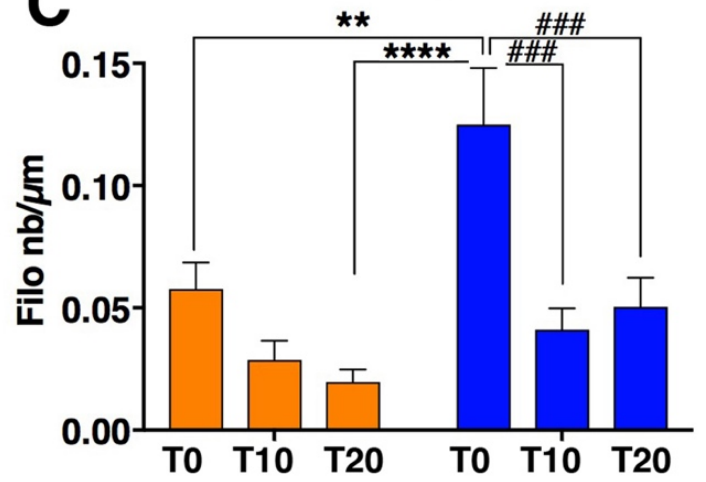

E

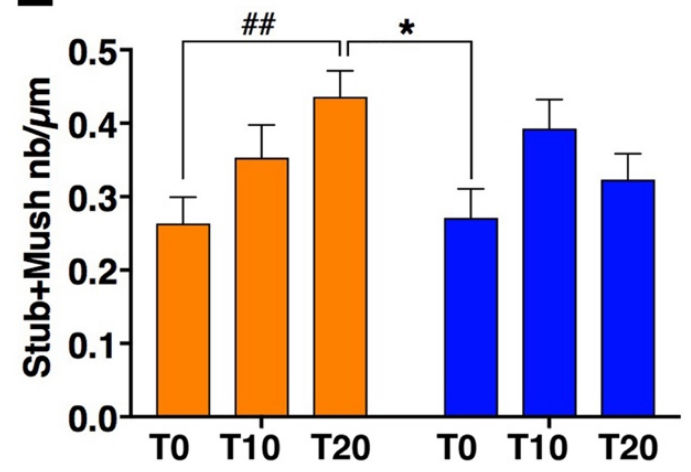


Figure 8 - CIPP expression and 5-HT $2 \mathrm{~B}$ receptor stimulation induce the formation of new dendritic spines. (A) Top: Morphological classification of dendritic spines. Middle: Representative images of dendritic spines of neurons co-transfected with plasmids encoding eGFP and 5- $\mathrm{HT}_{2 \mathrm{~B}}$ receptor, and either a plasmid encoding CIPP (+CIPP) or an empty vector (-CIPP) and exposed or not (T0) to BW723C86 $(1 \mu \mathrm{M})$ for 10 (T10) or 20 (T20) minutes. Bottom: Selected images from real-time imaging of neurons co-transfected with plasmids encoding eGFP and 5- $\mathrm{HT}_{2 \mathrm{~B}}$ receptor, before and after 10 and 20 minutes of stimulation by BW723C86 $(1 \mu \mathrm{M})$, for full recording, see (Supp Movie). Scale bars $5 \mu \mathrm{m}$. (B-E) Quantification of CIPP expression and/or 5-HT $2 \mathrm{~B}$ receptor stimulation on dendritic spines. In basal (T0) activity conditions, CIPP increases the total number of dendritic spines under basal activity conditions (T0) $(\mathrm{p}<0.0001, \mathrm{n}=17-18)(\mathbf{B})$, and the number of filopodia $(p=0.0011)(\mathbf{C})$ and immature (Thin and Long Thin) $(p<0.0001)$ spines (D) but not that of mature, Stubby and Mushroom (Stub+Mush) $(p=0.998)$ spines $(\mathbf{E})$.

BW723C86 stimulation of 5- $\mathrm{HT}_{2 \mathrm{~B}}$ receptors increases the overall number of spines in the absence of CIPP after 10 and 20 min of treatment (T0 vs. T10 $p=0.010$, T0 vs. T20 $p=0.004, n=18-18-20$ ) (B), and both immature Thin + Long Thin (T0 vs. T10 p =0.0124, T0 vs. T20 p=0.0186, n = 1818-22) spines (D) and mature Stub+Mush (T0 vs. T20 $\mathrm{p}=0.0029, \mathrm{n}=18-22)$ spines $(\mathbf{E})$ in neurons expressing the receptor alone.

BW723C86 stimulation of 5- $\mathrm{HT}_{2 \mathrm{~B}}$ receptors has no effect on the overall number of spines in neurons expressing CIPP (T0 vs. T10 $\mathrm{p}=0.500$, T0 vs. T20 $\mathrm{p}=0.863, \mathrm{n}=17-11-13)(\mathbf{B})$, decreases the density of filopodia (T0 vs. T10 p $=0.0003$, T0 vs. T20 p=0.0007, $n=18-11-13$ ) (C) in neurons expressing $5-\mathrm{HT}_{2 \mathrm{~B}}$ receptor $+\mathrm{CIPP}$, while it has no main impact on immature Thin + Long Thin (T0 vs. T10 $\mathrm{p}=0.738$, T0 vs. T20 $\mathrm{p}=0.750, \mathrm{n}=18-11-13$ ) spines (D) and mature Stub+Mush (T0 vs. T10 p=0.148, T0 vs. T20 p=0.691, $\mathrm{n}=16-13-13)$ spines $(\mathbf{E})$. Data were analyzed by two-way ANOVA and Tukey's multiple comparisons test. Data are from 2 neuronal cultures. \#\#\# $\mathrm{p}<0.001$, $\# \#$ p $<0.01, \# \mathrm{p}<0.05$ vs. t0; $* * * * \mathrm{p}<0.0001, * * * \mathrm{p}<0.001, * * \mathrm{p}<0.01, * \mathrm{p}<0.055-\mathrm{HT}_{2 B}$ Vs. $5-\mathrm{HT}_{2 \mathrm{~B}}+\mathrm{CIPP}$. 
Title: The serotonin 2B receptor by interacting with NMDA receptor and CIPP protein complex may control structural plasticity at glutamatergic synapses

Authors list: Amina Benhadda ${ }^{1 *}$, Emily Quentin ${ }^{1 *}$, Imane Moutkine ${ }^{1}$, Benjamin Chanrion ${ }^{2}$, Marion Russeau ${ }^{1}$, Philippe Marin ${ }^{2}$, Sabine Levi $^{1} \#$, and Luc Maroteaux ${ }^{1} \#$

\section{Supporting Information.}

Table S1: Characteristics of 5-HT $2 \mathrm{~B}$ receptor clusters in neurons expressing the receptor alone or in combination with CIPP (Illustrated on figure 3C-D and 5A-B).

\begin{tabular}{|c|c|c|c|c|c|}
\hline & & & $\begin{array}{l}\text { Cluster density } \\
\text { (number/ } \mathrm{\mu m} \text { ) }\end{array}$ & $\begin{array}{c}\text { Cluster Area } \\
\left(\mu \mathrm{m}^{2}\right)\end{array}$ & $\begin{array}{c}\text { Cluster intensity } \\
\text { (a.u.) }\end{array}$ \\
\hline \multirow[t]{2}{*}{ Total } & \multirow[t]{2}{*}{ to } & $5-\mathrm{HT}_{2 \mathrm{~B}}$ & $0.008 \pm 0.0004$ & $12.13 \pm 0.70$ & $843.64 \pm 75.76$ \\
\hline & & $5-\mathrm{HT}_{2 \mathrm{~B}}+\mathrm{CIPP}$ & $0.007 \pm 0.0004$ & $14.86 \pm 1.42$ & $964.09 \pm 45.32$ \\
\hline \multirow{6}{*}{ Surface } & \multirow[t]{2}{*}{ to } & $5-\mathrm{HT}_{2 \mathrm{~B}}$ & $0.021 \pm 0.001$ & $6.89 \pm 0.29$ & $793.21 \pm 34.68$ \\
\hline & & $5-\mathrm{HT}_{2 \mathrm{~B}}+\mathrm{CIPP}$ & $0.015 \pm 0.0009$ & $7.07 \pm 0.37$ & $926.66 \pm 55.86$ \\
\hline & \multirow[t]{2}{*}{$\mathrm{t} 10$} & $5-\mathrm{HT}_{2 \mathrm{~B}}$ & $0.019 \pm 0.0017$ & $6.80 \pm 0.55$ & $871.59 \pm 76.63$ \\
\hline & & $5-\mathrm{HT}_{2 \mathrm{~B}}+\mathrm{CIPP}$ & $0.015 \pm 0.0009$ & $6.40 \pm 0.37$ & $841.07 \pm 59.10$ \\
\hline & \multirow[t]{2}{*}{ t20 } & $5-\mathrm{HT}_{2 \mathrm{~B}}$ & $0.015 \pm 0.0013$ & $8.99 \pm 0.62$ & $1134.46 \pm 85.86$ \\
\hline & & $5-\mathrm{HT}_{2 \mathrm{~B}}+\mathrm{CIPP}$ & $0.016 \pm 0.0009$ & $6.99 \pm 0.37$ & $855.00 \pm 40.16$ \\
\hline
\end{tabular}

Table S2: Antibodies used for immunolabeling.

\begin{tabular}{llllll}
\hline Antibody/antigen & Clone & Label & Company & Reference & RRID \\
\hline HA-Tag & C29F4 & none & Cell Signaling & 3724 & AB_1549585 \\
\hline Flag-Tag & M5 & none & Sigma & F1804 & AB_262044 \\
\hline Flag-Tag & - & none & Sigma & F7425 & AB_439687 \\
\hline NR1 & 54.1 & none & Millipore & MAB363 & AB_94946 \\
\hline MAP-2 & - & none & Abcam & ab5392 & AB_2138153 \\
\hline Neurofilament & RT-97 & none & Millipore & MAB5262 & AB_95186 \\
\hline GFP & - & none & Aves & MAB363 & AB_2307313 \\
\hline Donkey anti-chicken & - & Cy3 & Jackson IR & $703-165-155$ & AB_2340363 \\
\hline Goat anti-rabbit & - & Cy3 & Jackson IR & $111-165-003$ & AB_2338000 \\
\hline Donkey anti-mouse & - & Cy5 & Jackson IR & $715-175-150$ & AB_2340819 \\
\hline
\end{tabular}


Table S3: Statistical analysis

\begin{tabular}{|c|c|c|c|c|c|c|c|c|}
\hline Paradigm or assay & $\begin{array}{l}\text { Measured } \\
\text { parameter }\end{array}$ & $\mathrm{n}$ & Statistical test & Comparison & Statistics & $\begin{array}{c}\begin{array}{c}\text { Degree of } \\
\text { freedom }\end{array} \\
\end{array}$ & $\mathrm{p}$ & Figure \\
\hline $\begin{array}{c}3 \mathrm{H}-\text { Mesulergine total } \\
\text { binding }\end{array}$ & Bmax & 3-3 & $\begin{array}{l}\text { Mann-Whitney } \\
\text { Unpaired t test }\end{array}$ & 5-HT2B vs. 5-HT2B/CIPP & & & 0.700 & 2.A Left \\
\hline $\begin{array}{c}\text { 3H-Mesulergine } \\
\text { surface binding } \\
\end{array}$ & Bmax & $3-3$ & $\begin{array}{l}\text { Mann-Whitney } \\
\text { Unpaired t test }\end{array}$ & 5-HT2B vs. 5-HT2B/CIPP & & & 0.100 & 2.A Right \\
\hline \multirow{5}{*}{ Inositol Phosphate } & $\begin{array}{c}\text { IP accumulation Emin } \\
5-\mathrm{HT}\end{array}$ & $5-5$ & $\begin{array}{l}\text { Mann-Whitney } \\
\text { Unpaired t test }\end{array}$ & 5-HT2B vs. 5-HT2B/CIPP & & & 0.0159 & \multirow{5}{*}{ 2.B Right } \\
\hline & $\begin{array}{c}\text { IP accumulation } \\
\text { Emax 5-HT }\end{array}$ & $4-4$ & $\begin{array}{l}\text { Mann-Whitney } \\
\text { Unpaired t test }\end{array}$ & 5-HT2B vs. 5-HT2B/CIPP & & & 0.0286 & \\
\hline & \begin{tabular}{|c} 
IP accumulation Emin \\
DOI \\
\end{tabular} & $4-4$ & $\begin{array}{l}\text { Mann-Whitney } \\
\text { Unpaired t test }\end{array}$ & 5-HT2B vs. $5-\mathrm{HT} 2 \mathrm{~B} / \mathrm{CIPP}$ & & & 0.0286 & \\
\hline & \begin{tabular}{|c|} 
IP accumulation \\
Emax DOI \\
\end{tabular} & $4-4$ & $\begin{array}{l}\text { Mann-Whitney } \\
\text { Unpaired t test }\end{array}$ & 5-HT2B vs. 5-HT2B/CIPP & & & 0.0286 & \\
\hline & $\log (\mathrm{T} / \mathrm{KA})$ & $6-6$ & $\begin{array}{l}\text { Mann-Whitney } \\
\text { Unpaired t test }\end{array}$ & 5-HT2B vs. 5-HT2B/CIPP & & & 0.8182 & \\
\hline \multirow{6}{*}{$\begin{array}{l}\text { 5-HT2B receptor } \\
\text { clusters }\end{array}$} & Total number & $46-49$ & Unpaired $t$ test & 5-HT2B vs. 5-HT2B/CIPP & $\mathrm{t}=1.751$ & 93 & 0.083 & \multirow{6}{*}{ 3.E } \\
\hline & Surface number & $51-53$ & Unpaired $t$ test & 5-HT2B vs. 5-HT2B/CIPP & $\mathrm{t}=4.978$ & 102 & $<0.0001$ & \\
\hline & Total area & $45-48$ & Unpaired $t$ test & 5-HT2B vs. 5-HT2B/CIPP & $t=2.287$ & 91 & 0.024 & \\
\hline & Surface area & $49-49$ & Unpaired $\mathrm{t}$ test & 5-HT2B vs. 5-HT2B/CIPP & $t=2.19652$ & & 0.034 & \\
\hline & $\begin{array}{c}\text { Total integrated } \\
\text { intensity }\end{array}$ & $45-49$ & Unpaired $\mathrm{t}$ test & 5-HT2B vs. $5-\mathrm{HT} 2 \mathrm{~B} / \mathrm{CIPP}$ & $t=3.42$ & 92 & 0.0009 & \\
\hline & $\begin{array}{c}\text { Surface integrated } \\
\text { intensity }\end{array}$ & $51-51$ & Unpaired $t$ test & 5-HT2B vs. 5-HT2B/CIPP & $t=3.746$ & 100 & 0.0003 & \\
\hline \multirow{12}{*}{$\begin{array}{l}\text { 5-HT2B receptor } \\
\text { clusters }\end{array}$} & \multirow{4}{*}{$\begin{array}{l}\text { 5-HT2B receptor } \\
\text { cluster number }\end{array}$} & & One way ANOVA & & $F=3.349$ & 2,40 & 0.0452 & \multirow{12}{*}{$3 . G$} \\
\hline & & $17-13$ & \multirow{3}{*}{ Tukey's post-test } & 5-HT2B vs. 5-HT2B TAT-Cter & & & 0.0493 & \\
\hline & & $17-13$ & & 5-HT2B vs. 5-HT2B TAT-Cter-M & & & 0.9576 & \\
\hline & & $13-13$ & & 5-HT2B TAT-Cter vs. 5-HT2B TAT-Cter-M & & & 0.1185 & \\
\hline & \multirow{8}{*}{$\begin{array}{l}\text { 5-HT2B receptor } \\
\text { cluster integrated } \\
\text { intensity }\end{array}$} & & One way ANOVA & & $F=6.542$ & 2,40 & 0.0035 & \\
\hline & & $18-13$ & \multirow{3}{*}{ Tukey's post-test } & 5-HT2B vs. 5-HT2B TAT-Cter & & & 0.0036 & \\
\hline & & $18-12$ & & 5-HT2B vs. 5-HT2B TAT-Cter-M & & & 0.8848 & \\
\hline & & $13-12$ & & 5-HT2B TAT-Cter vs. 5-HT2B TAT-Cter-M & & & 0.0260 & \\
\hline & & & One way ANOVA & & $F=9.659$ & 2,41 & 0.0004 & \\
\hline & & $18-13$ & \multirow{3}{*}{ Tukey's post-test } & 5-HT2B vs. 5-HT2B TAT-Cter & & & 0.0009 & \\
\hline & & $18-13$ & & \begin{tabular}{|l|} 
5-HT2B vs. 5-HT2B TAT-Cter-M \\
\end{tabular} & & & 0.9946 & \\
\hline & & 13-13 & & 5-HT2B TAT-Cter vs. 5-HT2B TAT-Cter-M & & & 0.0015 & \\
\hline \multirow{2}{*}{$\%$ Colocalization } & Homer & $24-23$ & Unpaired $t$ test & 5-HT2B vs. 5-HT2B/CIPP & $\mathrm{t}=0.4723$ & 45 & 0.639 & 4.C left \\
\hline & Gephyrin & $25-23$ & Unpaired $\mathrm{t}$ test & 5-HT2B vs. 5-HT2B/CIPP & $t=2.391$ & 46 & 0.021 & 4.C right \\
\hline \multirow{24}{*}{$\begin{array}{l}5-\mathrm{HT} 2 \mathrm{~B} \text { receptor } \\
\text { kinetic stimulation }\end{array}$} & \multirow{8}{*}{$\begin{array}{l}\text { 5-HT2B receptor } \\
\text { cluster number }\end{array}$} & & One way ANOVA & & $\mathrm{F}=18.3$ & 2,140 & $<0.0001$ & \multirow{24}{*}{$5 . \mathrm{B}$} \\
\hline & & $47-46$ & \multirow{3}{*}{ Tukey's post-test } & 5-HT2B t0 vs. 5-HT2B t10 & & & 0.0044 & \\
\hline & & $47-50$ & & 5-HT2B to vs. 5-HT2B t20 & & & $<0.0001$ & \\
\hline & & $46-50$ & & 5-HT2B t10 vs. 5-HT2B t20 & & & 0.0192 & \\
\hline & & & One way ANOVA & & $F=0.3124$ & 2,131 & 0.7322 & \\
\hline & & $45-44$ & \multirow{3}{*}{ Tukey's post-test } & 5-HT2B/CIPP t0 vs. 5-HT2B/CIPP t10 & & & 0.9761 & \\
\hline & & $45-45$ & & 5-HT2B/CIPP t0 vs. 5-HT2B/CIPP t20 & & & 0.7248 & \\
\hline & & $44-45$ & & 5-HT2B/CIPP t10 vs. 5-HT2B/CIPP t20 & & & 0.8458 & \\
\hline & & & One way ANOVA & & $F=2.835$ & 2,123 & 0.0626 & \\
\hline & & $46-41$ & \multirow{3}{*}{ Tukey's post-test } & 5-HT2B to vs. 5-HT2B t10 & & & 0.1509 & \\
\hline & & $46-39$ & & 5-HT2B t0 vs. 5-HT2B t20 & & & 0.9028 & \\
\hline & 5-HT2B receptor & 41-39 & & 5-HT2B t10 vs. 5-HT2B t20 & & & 0.0722 & \\
\hline & cluster area & & One way ANOVA & & $F=3.093$ & 2,128 & 0.0488 & \\
\hline & & $43-43$ & & 5-HT2B/CIPP t0 vs. 5-HT2B/CIPP t10 & & & 0.0724 & \\
\hline & & 43-45 & Tukey's post-test & 5-HT2B/CIPP t0 vs. 5-HT2B/CIPP t20 & & & 0.9885 & \\
\hline & & $43-45$ & & 5-HT2B/CIPP t10 vs. 5-HT2B/CIPP t20 & & & 0.0947 & \\
\hline & & & One way ANOVA & & $F=0.8794$ & 2,128 & 0.4175 & \\
\hline & & $47-44$ & & 5-HT2B to vs. 5-HT2B t10 & & & 0.9488 & \\
\hline & & $47-40$ & Tukey's post-test & 5-HT2B to vs. 5-HT2B t20 & & & 0.4076 & \\
\hline & $\begin{array}{l}5 \text {-HT2B receptor } \\
\text { cluster integrated }\end{array}$ & $44-40$ & & 5-HT2B t10 vs. 5-HT2B t20 & & & 0.5991 & \\
\hline & intensity & & One way ANOVA & & $F=2.402$ & 2,131 & 0.00945 & \\
\hline & & $45-44$ & & 5-HT2B/CIPP t0 vs. 5-HT2B/CIPP t10 & & & 0.0771 & \\
\hline & & $45-45$ & Tukey's post-test & 5-HT2B/CIPP t0 vs. 5-HT2B/CIPP t20 & & & 0.4483 & \\
\hline & & $44-45$ & & 5-HT2B/CIPP t10 vs. 5-HT2B/CIPP t20 & & & 0.5894 & \\
\hline & Peak height & $133-230$ & $\begin{array}{l}\text { Mann-Whitney } \\
\text { Unpaired t test }\end{array}$ & 5-HT2B vs. 5-HT2B/CIPP & & & 0.0056 & 6.C \\
\hline Calcium signal tro & AUC & $49-143$ & $\begin{array}{l}\text { Mann-Whitney } \\
\text { Unpaired t test }\end{array}$ & 5-HT2B vs. 5-HT2B/CIPP & & & $<0.0001$ & 6.D \\
\hline
\end{tabular}




\begin{tabular}{|c|c|c|c|c|c|c|c|c|}
\hline Paradigm or assay & $\begin{array}{l}\text { Measured } \\
\text { parameter }\end{array}$ & $\mathrm{n}$ & Statistical test & Comparison & Statistics & $\begin{array}{c}\text { Degree of } \\
\text { freedom }\end{array}$ & $\mathrm{p}$ & Figure \\
\hline \multirow{24}{*}{$\begin{array}{l}\text { Effect of 5-HT2B } \\
\text { receptor stimulation } \\
\text { on NR1 clusters }\end{array}$} & \multirow{8}{*}{$\begin{array}{c}\text { Number of NR1/5- } \\
\text { HT2B clusters }\end{array}$} & $28-27$ & Unpaired $\mathrm{t}$ test & $5-\mathrm{HT} 2 \mathrm{~B}$ to vs. $5-\mathrm{HT} 2 \mathrm{~B}+\mathrm{CIPP}$ t0 & $t=2.041$ & 53 & 0.0463 & \multirow{8}{*}{ 7.B } \\
\hline & & & One way ANOVA & & $F=5.362$ & 2,79 & 0.0066 & \\
\hline & & $26-26$ & \multirow{2}{*}{$\begin{array}{c}\text { Holm-Sidak's post- } \\
\text { test }\end{array}$} & 5-HT2B to vs. 5-HT2B t10 & & & 0.0035 & \\
\hline & & $26-28$ & & 5-HT2B t0 vs. 5-HT2B t20 & & & 0.0413 & \\
\hline & & & One way ANOVA & & $\mathrm{F}=0.2857$ & 2,74 & 0.7523 & \\
\hline & & $27-27$ & \multirow{2}{*}{$\begin{array}{c}\text { Holm-Sidak's post- } \\
\text { test }\end{array}$} & 5-HT2B/CIPP t0 vs. 5-HT2B/CIPP t10 & & & 0.7023 & \\
\hline & & $27-23$ & & 5-HT2B/CIPP to vs. 5-HT2B/CIPP t20 & & & 0.7023 & \\
\hline & & 28-25 & Unpaired t test & 5-HT2B t20 vs. 5-HT2B+CIPP t20 & $t=1.014$ & 51 & 0.3152 & \\
\hline & \multirow{8}{*}{$\begin{array}{c}\text { Area of NR1/5-HT2B } \\
\text { clusters }\end{array}$} & $22-22$ & Unpaired $t$ test & 5-HT2B t0 vs. 5-HT2B+CIPP t0 & $t=0.8639$ & 42 & 0.3925 & \multirow{8}{*}{ 7.C } \\
\hline & & & One way ANOVA & & $F=0.6896$ & 2,79 & 0.5048 & \\
\hline & & $26-28$ & Holm-Sidak's post- & 5-HT2B to vs. 5-HT2B t10 & & & 0.7662 & \\
\hline & & $26-28$ & test & 5-HT2B t10 vs. 5-HT2B t20 & & & 0.7662 & \\
\hline & & & One way ANOVA & & $F=0.6921$ & 2,74 & 0.5037 & \\
\hline & & $27-25$ & \multirow{2}{*}{$\begin{array}{c}\text { Holm-Sidak's post- } \\
\text { test }\end{array}$} & 5-HT2B/CIPP t0 vs. 5-HT2B/CIPP t10 & & & 0.9563 & \\
\hline & & $27-25$ & & 5-HT2B/CIPP t10 vs. 5-HT2B/CIPP t20 & & & 0.5357 & \\
\hline & & 28-25 & Unpaired t test & 5-HT2B t20 vs. 5-HT2B+CIPP t20 & $t=0.00538$ & 51 & 0.9957 & \\
\hline & \multirow{8}{*}{$\begin{array}{l}\text { Integrated intensity of } \\
\text { NR1/5-HT2B clusters }\end{array}$} & $28-27$ & Unpaired $\mathrm{t}$ test & 5-HT2B t0 vs. 5-HT2B+CIPP t0 & $\mathrm{t}=0.637$ & 53 & 0.5269 & \multirow{8}{*}{ 7.D } \\
\hline & & & One way ANOVA & & $\mathrm{F}=0.7118$ & 2,79 & 0.4939 & \\
\hline & & $26-28$ & \multirow{2}{*}{$\begin{array}{c}\text { Holm-Sidak's post- } \\
\text { test }\end{array}$} & 5-HT2B to vs. 5-HT2B t10 & & & 0.4774 & \\
\hline & & $26-28$ & & 5-HT2B t10 vs. $5-\mathrm{HT} 2 \mathrm{~B}$ t20 & & & 0.8725 & \\
\hline & & & One way ANOVA & & $F=3.334$ & 2,75 & 0.041 & \\
\hline & & $27-27$ & \multirow{2}{*}{$\begin{array}{c}\text { Holm-Sidak's post- } \\
\text { test }\end{array}$} & 5-HT2B/CIPP t0 vs. 5-HT2B/CIPP t10 & & & 0.0712 & \\
\hline & & $27-24$ & & 5-HT2B/CIPP t10 vs. 5-HT2B/CIPP t20 & & & 0.8112 & \\
\hline & & $28-25$ & Unpaired $\mathrm{t}$ test & 5-HT2B t20 vs. $5-\mathrm{HT} 2 \mathrm{~B}+\mathrm{CIPP}$ t20 & $\mathrm{t}=0.9971$ & 51 & 0.3234 & \\
\hline \multirow{8}{*}{ Spine number } & \multirow{8}{*}{$\mathrm{Nb} / \mu \mathrm{m}$} & & \multirow{3}{*}{ Two-way ANOVA } & Interaction & $\mathrm{F}=1.642$ & 2,91 & 0.1992 & \multirow{8}{*}{$8 . B$} \\
\hline & & & & Factor Time & $F=4.956$ & 2,91 & 0.0091 & \\
\hline & & & & Factor Transfection & $F=25.82$ & 1,91 & $<0.0001$ & \\
\hline & & $18-17$ & & T0 5-HT2B vs. T0 5-HT2B+CIPP & & & $<0.0001$ & \\
\hline & & $18-13$ & & T0 5-HT2B vs. T20 5-HT2B+CIPP & & & 0.0001 & \\
\hline & & $18-11$ & Tukey's post-test & T10 5-HT2B vs. T10 5-HT2B+CIPP & & & 0.0366 & \\
\hline & & $18-18$ & & T0 5-HT2B vs. T10 5-HT2B & & & 0.0104 & \\
\hline & & $18-20$ & & T0 5-HT2B vs. T20 5-HT2B & & & 0.0041 & \\
\hline \multirow{7}{*}{ Filopodia } & \multirow{7}{*}{$\mathrm{Nb} / \mu \mathrm{m}$} & & & Interaction & $F=2.111$ & 2,86 & 0.1274 & \\
\hline & & & Two-way ANOVA & Factor Time & $\mathrm{F}=11.86$ & 2,86 & $<0.0001$ & \\
\hline & & & & Factor Transfection & $F=10.52$ & 1,86 & 0.0017 & \\
\hline & & $17-18$ & & T0 5-HT2B vs. T0 5-HT2B+CIPP & & & 0.0011 & 8.C \\
\hline & & $17-18$ & Tukev's nost-test & T20 5-HT2B vs. T0 5-HT2B+CIPP & & & $<0.0001$ & \\
\hline & & $18-11$ & tukeys post-iest & T0 5-HT2B+CIPP vs. T10 5-HT2B+CIPP & & & 0.0003 & \\
\hline & & $18-13$ & & T0 5-HT2B+CIPP vs. T20 5-HT2B+CIPP & & & 0.0007 & \\
\hline & & & & \begin{tabular}{|c|} 
Interaction \\
\end{tabular} & $\mathrm{F}=1.189$ & 2,94 & 0.309 & \\
\hline & & & Two-way ANOVA & Factor Time & $\mathrm{F}=4.03$ & 2,94 & 0.0209 & \\
\hline & & & & Factor Transfection & $F=35.88$ & 1,94 & $<0.0001$ & \\
\hline & & $18-18$ & & T0 5-HT2B vs. T0 5-HT2B+CIPP & & & $<0.0001$ & \\
\hline $\begin{array}{l}\text { Immature spines } \\
\text { (Thin and Long-thin) }\end{array}$ & $\mathrm{Nb} / \mu \mathrm{m}$ & $18-13$ & & T0 5-HT2B vs. T20 5-HT2B+CIPP & & & $<0.0001$ & $8 . \mathrm{D}$ \\
\hline & & $18-11$ & Tukey's post-test & T10 5-HT2B vs. T10 5-HT2B+CIPP & & & 0.0361 & \\
\hline & & $22-13$ & & T20 5-HT2B vs. T20 5-HT2B+CIPP & & & 0.0104 & \\
\hline & & $18-18$ & & T0 5-HT2B vs. T10 5-HT2B & & & 0.0124 & \\
\hline & & $18-22$ & & T0 5-HT2B vs. T20 5-HT2B & & & 0.0186 & \\
\hline & & & & Interaction & $F=2.025$ & 2,91 & 0.1379 & \\
\hline & & & Two-way ANOVA & Factor Time & $\mathrm{F}=4.941$ & 2,91 & 0.0092 & \\
\hline (Stubby and & $\mathrm{Nb} / \mu \mathrm{m}$ & & & Factor Transfection & $F=0.4782$ & 1,91 & 0.491 & 8.E \\
\hline Mushrom) & & $22-18$ & Tukev's post-test & \begin{tabular}{|l} 
T20 5-HT2B vs. T0 5-HT2B \\
\end{tabular} & & & 0.0029 & \\
\hline & & $16-13$ & & T0 5-HT2B+CIPP vs. T20 5-HT2B+CIPP & & & 0.691 & \\
\hline
\end{tabular}




\begin{tabular}{|c|c|c|c|c|c|c|c|c|}
\hline Paradigm or assay & $\begin{array}{l}\text { Measured } \\
\text { parameter }\end{array}$ & $\mathrm{n}$ & Statistical test & Comparison & Statistics & $\begin{array}{l}\text { Degree of } \\
\text { freedom }\end{array}$ & $\mathrm{p}$ & Figure \\
\hline \multirow{4}{*}{$\begin{array}{l}\text { 5-HT2B receptor } \\
\text { clusters }\end{array}$} & \multirow{4}{*}{$\begin{array}{l}\text { 5-HT2B receptor } \\
\text { cluster number }\end{array}$} & & One way ANOVA & & $F=3.753$ & 2,71 & 0.0282 & \multirow{4}{*}{ S1.A } \\
\hline & & $31-17$ & \multirow{3}{*}{ Tukey's post-test } & 5-HT2B vs. 5-HT2B + CIPP & & & 0.0213 & \\
\hline & & $31-26$ & & 5-HT2B vs. 5-HT2B $\triangle \mathrm{PDZ}+\mathrm{CIPP}$ & & & 0.6229 & \\
\hline & & $17-26$ & & $5-\mathrm{HT} 2 \mathrm{~B}+\mathrm{CIPP}$ vs. $5-\mathrm{HT} 2 \mathrm{~B} \Delta \mathrm{PDZ}+\mathrm{CIPP}$ & & & 0.1605 & \\
\hline \multirow{12}{*}{$\begin{array}{l}5 \text {-HT2B receptor } \\
\text { clusters }\end{array}$} & \multirow{4}{*}{$\begin{array}{l}\text { 5-HT2B receptor } \\
\text { cluster number }\end{array}$} & & One way ANOVA & & $\mathrm{F}=21$ & 3,159 & $<0.0001$ & \multirow{12}{*}{ S2.B } \\
\hline & & $71-15$ & \multirow{3}{*}{ Tukey's post-test } & 5-HT2B vs. 5-HT2B+BW50 & & & 0.2898 & \\
\hline & & $71-18$ & & 5-HT2B vs. 5-HT2B+BW100 & & & 0.0052 & \\
\hline & & $71-59$ & & 5-HT2B vs. 5-HT2B+BW1000 & & & $<0.0001$ & \\
\hline & \multirow{4}{*}{$\begin{array}{c}\text { 5-HT2B receptor } \\
\text { cluster area }\end{array}$} & & One way ANOVA & & $F=9.153$ & 3,159 & $<0.0001$ & \\
\hline & & $70-16$ & \multirow{3}{*}{ Tukey's post-test } & 5-HT2B vs. 5-HT2B+BW50 & & & 0.0959 & \\
\hline & & $70-18$ & & 5-HT2B vs. 5-HT2B+BW100 & & & 0.0622 & \\
\hline & & $70-59$ & & 5-HT2B vs. 5-HT2B+BW1000 & & & $<0.0001$ & \\
\hline & \multirow{4}{*}{$\begin{array}{c}\text { 5-HT2B receptor } \\
\text { cluster integrated } \\
\text { intensity }\end{array}$} & & One way ANOVA & & $\mathrm{F}=2.232$ & 3,151 & 0.0241 & \\
\hline & & $71-16$ & \multirow{3}{*}{ Tukey's post-test } & 5-HT2B vs. 5-HT2B+BW50 & & & 0.2561 & \\
\hline & & $71-18$ & & 5-HT2B vs. 5-HT2B+BW100 & & & 0.1246 & \\
\hline & & $71-50$ & & 5-HT2B vs. 5-HT2B+BW1000 & & & 0.0647 & \\
\hline \multirow{4}{*}{$\begin{array}{l}\mathrm{NR} 1 / 5-\mathrm{HT} 2 \mathrm{~B} \\
\text { receptor clusters }\end{array}$} & \multirow{4}{*}{$\begin{array}{l}\text { NR1/5-HT2B } \\
\text { receptor cluster } \\
\text { number }\end{array}$} & & One way ANOVA & & $F=4.02$ & 3,117 & 0.0092 & \multirow{4}{*}{ S2.C } \\
\hline & & $50-16$ & \multirow{3}{*}{ Tukey's post-test } & 5-HT2B vs. 5-HT2B+BW50 & & & 0.2948 & \\
\hline & & $50-18$ & & 5-HT2B vs. 5-HT2B+BW100 & & & 0.0649 & \\
\hline & & $50-37$ & & 5-HT2B vs. 5-HT2B+BW1000 & & & 0.0152 & \\
\hline
\end{tabular}


A

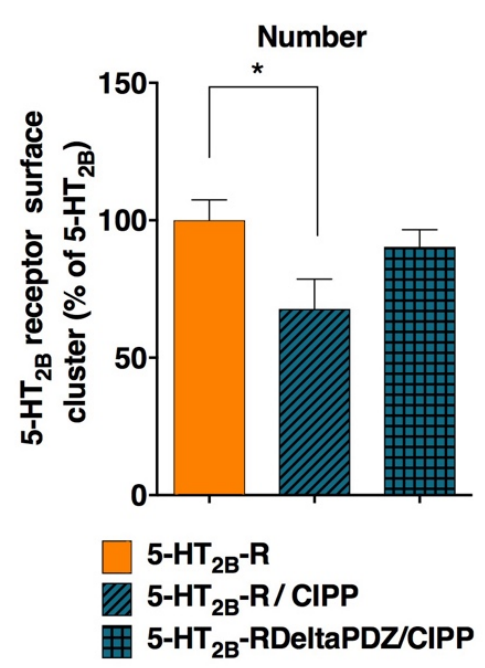

B

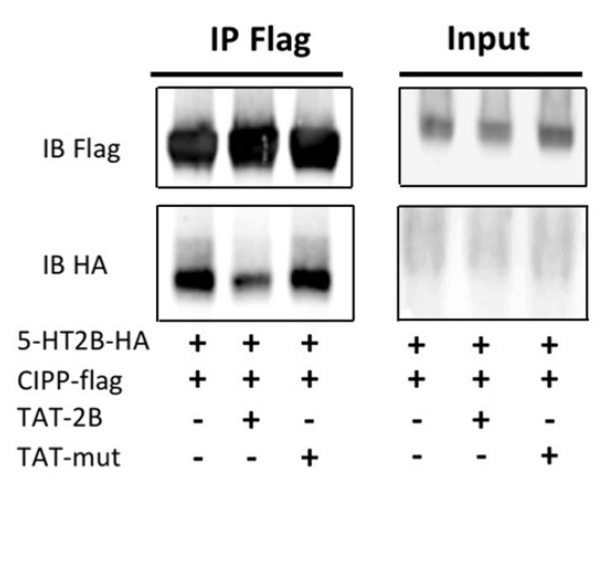

Figure S1 - (A) Quantification of 5-HT $2 \mathrm{~B}$ receptor clusters in neurons overexpressing (dark blue) or not (orange) CIPP in the presence of $5-\mathrm{HT}_{2 \mathrm{~B}}$ receptor $\triangle \mathrm{PDZ}$. The CIPP-induced decrease in $5-\mathrm{HT}_{2 \mathrm{~B}}$ receptor cluster number at the neuronal surface was not observed upon overexpression of $5-\mathrm{HT}_{2 \mathrm{~B}}$ receptor lacking the C-terminal motif $\left(5-\mathrm{HT}_{2 \mathrm{~B}}-\mathrm{R} \Delta \mathrm{PDZ}\right)$, in favor of an effect dependent on an interaction of CIPP with the PDZ domain of the receptor. Data, expressed as percentage of the value of 5- $\mathrm{HT}_{2 \mathrm{~B}}$ receptor alone, were analyzed by one-way ANOVA and Tukey's multiple comparisons test $\left(5-\mathrm{HT}_{2 \mathrm{~B}}\right.$ receptor vs. 5- $\mathrm{HT}_{2 \mathrm{~B}}$ receptor $+\mathrm{CIPP} \mathrm{p}=0.021, \mathrm{n}=17-31$ dendrites) from 2 neuronal cultures. $* \mathrm{p}<0.05$. (B) Co-immunoprecipitation of CIPP with the 5HT $_{2 B}$ receptor in COS-7 cells in the presence of TAT-peptides. Proteins from COS-7 cells cotransfected with plasmids coding for HA-tagged 5-HT $2 \mathrm{~B}$ receptor (5-HT2B-HA), Flag-tagged CIPP and/or the TAT-5-HT $2 \mathrm{~B}-\mathrm{C}$-ter SYV (TAT-2B) or mutated C-ter SSV (TAT-mut) were analyzed by Western blotting. Blot of input of proteins revealed by anti-Flag antiserum (IB Flag-CIPP) or by anti-HA antiserum (IB HA-2B) shows the presence of the proteins in each condition (right). Immunoprecipitations using anti-Flag beads (IP Flag-CIPP) or anti-HA beads (IP HA-2B) followed by Western blotting revealed an interaction between CIPP and 5- $\mathrm{HT}_{2 \mathrm{~B}}$ receptors which was reduced in the presence of TAT-2B, but not TAT-mut, indicating a selective competition between TAT-2B peptide and 5-HT2B receptors for CIPP binding. 

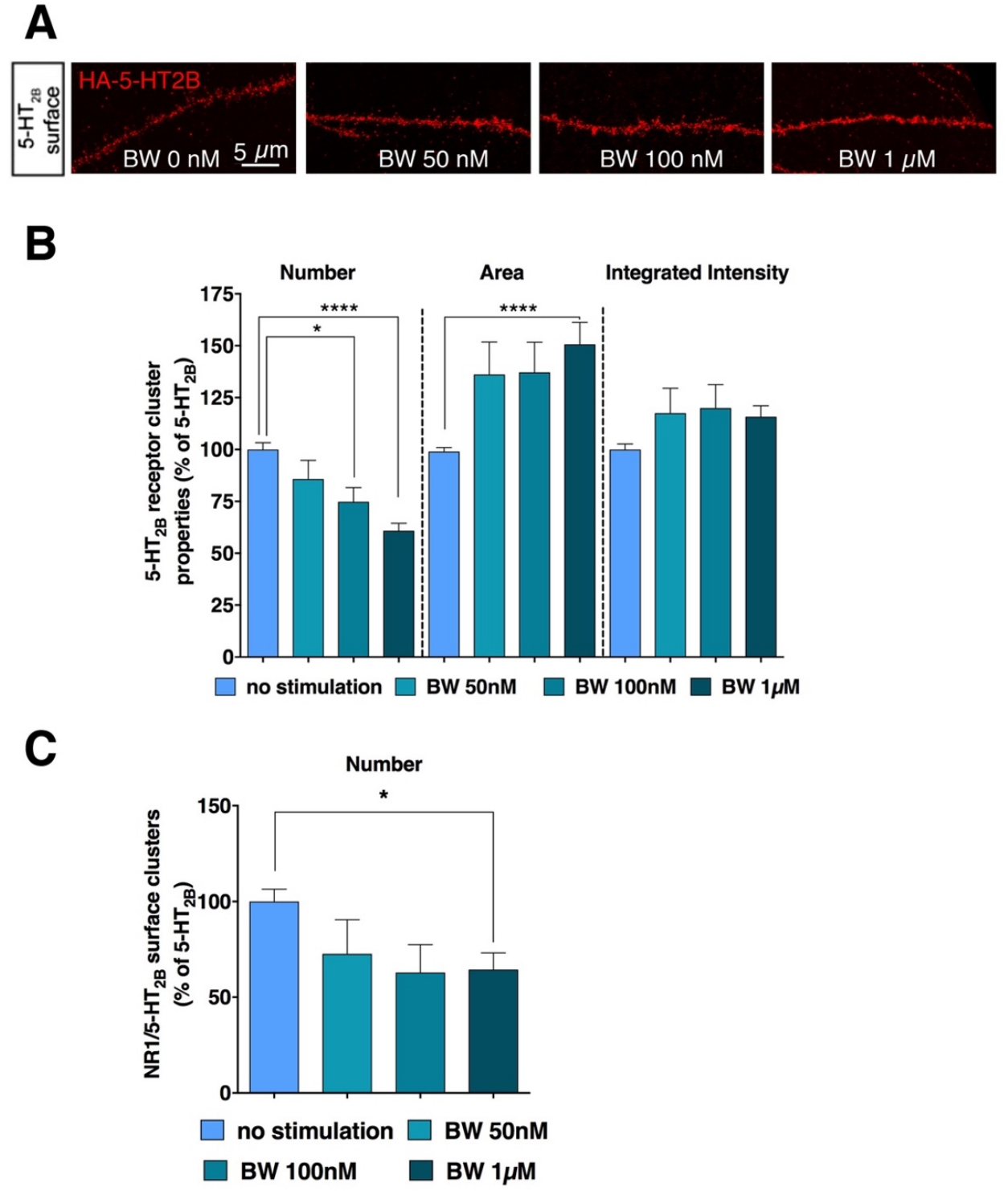

Fig. S2 Dose response effect of BW723C86 agonist on 5-HT $2 \mathrm{~B}$ receptor membrane clusters. (A) Representative images of 5- $\mathrm{HT}_{2 \mathrm{~B}}$ receptor clusters at the dendritic surface $20 \mathrm{~min}$ after BW723C 86 stimulation $(0,50,100,1 \mu \mathrm{M})$. Scale bars $5 \mu \mathrm{m}$. (B) Quantification of 5-HT $\mathbf{2 B}_{\mathbf{B}}$ receptor surface clustering following agonist stimulation. Upon $5-\mathrm{HT}_{2 \mathrm{~B}}$ receptor stimulation by $\mathrm{BW} 723 \mathrm{C} 86$, the number of $5-\mathrm{HT}_{2 \mathrm{~B}}$ receptor clusters at the neuronal surface decreased from 0 to $1 \mu \mathrm{M}(0$ vs. $100 \mathrm{nM}$ $\mathrm{p}=0.005,0$ vs. $1 \mu \mathrm{M} p<0.0001$, number of dendrites $=71-15-18-59)$. The agonist treatment significantly increased the size (area) $(0$ vs. $1 \mu \mathrm{M} \mathrm{p}<0.0001, \mathrm{n}=70-16-18-59)$ but not the molecular density (integrated intensity) of 5- $\mathrm{HT}_{2 \mathrm{~B}}$ receptor clusters. (C) Quantification showing the effect of BW723C86 on the number of NR1 clusters colocalized with 5-HT ${ }_{2 B}$ receptor clusters. Upon 5$\mathrm{HT}_{2 \mathrm{~B}}$ receptor stimulation by $\mathrm{BW} 723 \mathrm{C} 86$, the number of $\mathrm{NR} 1 / 5-\mathrm{HT}_{2 \mathrm{~B}}$ receptor clusters at the neuronal surface decreased from 0 to $1 \mu \mathrm{M}(0$ vs. $1 \mu \mathrm{M} \mathrm{p}=0.015$, number of dendrites $=50-16-18$ 370). Data, expressed as percentage of the basal values, were analyzed by one-way ANOVA and Tukey's multiple comparisons test. Data are from 2 cultures. $* * * * p<0.0001, * p<0.05$. 


\section{Supplementary movie}

Real-time live recordings of neuronal cultures overexpressing 5-HT2B-HA and eGFP before and after treatment by BW723C86 $(1 \mu \mathrm{M})$ : (SuppMovie_BW2.mp4) 